\title{
NOTES
}

\section{PROTECTING NATIONAL INTERESTS: \\ THE LEGAL STATUS OF \\ EXTRATERRITORIAL LAW \\ ENFORCEMENT BY THE \\ MILITARY}

Christopher A. DONESA

\section{INTRODUCTION}

With the collapse of the Soviet Union and the end of the Cold War, America's national security regime has increasingly looked to doinestic and international law for its guiding principles. ${ }^{1}$ Past einphasis on political ideology has given way in part to a broadly defined theory of "law enforceinent" as an important goal of foreign pohicy, increasing the practical stature and relevance of questions of international law and extraterritorial jurisdiction.

Legal concerns have dominated recent American actions and policies abroad, noving from the realm of largely academic sparring into questions of vital importance. Recent attention has focused on American efforts to extradite alleged terrorists responsible for the bombing of Pan Am flight 103, accompanied by hints that stronger action to retrieve thein may result otherwise. ${ }^{2}$ The formation of the allied coalition agamst Iraq in the Gulf War of 1991 drew nuch of its foundation from a newfound respect for principles of international law. ${ }^{3}$ Just as significantly, American military action in Panania drew as much of its formal justification from principles of U.S. domestic law as fronı the law of nations. ${ }^{4}$

1. See W. Michael Reisman, Editorial Comment, International Law After the Cold War, 84 AM. J. INT'L L. 859 (1990).

2. See Rupert Cornwell, The Lockerbie Bombing: US Reviews Options to Bring Accused to Trial, The INDEPENDENT (London), Nov. 16, 1991, at 13 ("[N]either the White House nor anyone else in authority would dwell publicly on the unspecified 'options' aired menacingly by Presidential spokesman Marlin Fitzwater .....").

3. See, e.g., S.C. Res. 678, U.N. SCOR, 2963d mtg., U.N. Doc. S/RES/678 (1990) (authorizing use of force by member nations to carry out Security Council mandate).

4. See Elaine S. Povich, U.S. Seeks to Build Legal Case for Invasion, CHI. Trib., Dec. 21, $1989, \S 1$, at 16 . 
The breadth of American enforcement jurisdiction in foreign countries has also seen significant expansion by the courts and the executive branch. The Supreme Court recently held that some constitutional protections do not apply overseas when the government takes action against foreign nationals. ${ }^{5}$ This decision followed closely on the heels of two controversial opinions by the Justice Department's Office of Legal Counsel construing domestic law to allow the American military and law enforcement agents the power to arrest foreign nationals outside American borders. ${ }^{6}$

The emerging claim of a "new world order"7 thus rests on two pillars: newfound respect for sweeping principles of international law in relations between nations; and increasing willingness to act abroad against individuals or private groups to enforce narrower classes of domestic laws that inipact American imterests on a global scale. The latter category, in effect, transforms some categories of law enforceinent into national security issues, most notably issues such as terrorism and narcotics trafficking. ${ }^{8}$ As national security becomes defined as much by law as pohtics, the military will assume an increasing role in law enforcement, particularly overseas. In turn, policymakers must take increasing care to ensure that enforcement actions themselves are in compliance with legal norms.

The potential for extraterritorial law enforcement by the military highlights two fundamental tensions. First, any action taken abroad must be reconciled with the general presumption that nations retain sovereignty within their own territory. Without the approval of foreign nations, American agents who operate abroad risk offending comity

5. See United States v. Verdugo-Urquidez, 494 U.S. 259 (1990).

6. The opinions have not been released to the public. For a general summary, see Michael Isikoff \& Patrick E. Tyler, U.S. Military Given Foreign Arrest Powers, WASH. Post, Dec. 16, 1989, at A1; Ruth Marcus, Justice Department Says FBI Can Seize Fugitives Overseas; Carter-Era Ban on Making Arrests Without Foreign Nations' Consent is Called "Flawed", WASH. Post, Nov. 9, 1989, at A72; infra text accompanying notes 93-107.

7. President Bush defined the policy at the start of the Persian Gulf War. "We have before us the opportunity to forge for ourselves and for future generations a new world order, a world where the rule of law, not the law of the jungle governs the conduct of nations." Transcript of the Comments by Bush on the Air Strikes Against the Iragis, N.Y. TIMEs, Jan. 17, 1991, at A14.

8. Defining these areas of the law is at best an art form that defies easy categorization. Generally speaking, we can understand them as challenges to American society and interests posed abroad outside the traditional framework of ambivalent or unfriendly government action. Two concrete examples are terrorism against American citizens, which is specifically criminalized worldwide by 18 U.S.C. $\$ 2331$ (1988), and narcotics trafficking. Many other offenses have the potential to fit within this framework, including environmental and cconomic offenses. Counterespionage against foreign industrial spies, for example, is reported to be a rising priority for the Central Intelligence Agency. See George Lardner, Jr., CIA Seeks to Define New Role; Economic Espionage Sparks Wide Debate, WASh. Post, Nov. 13, 1990, at Al. These offenses are almost always criminal. 
between nations as well as the imternational legal system. In some cases, they may expose themselves to criminal liability within other countries.9 The challenge is to determine in which areas such enforcement is legitimate and proper within the boundaries of international law, or if some situations are so extraordmary as to dictate reduced deference to its principles.

Second, the potential for the military to enforce American civil laws strams a long-held presumption that the two should remain separate to protect the rights and civil hiberties of citizens. We must ask, then, under what circumstances it is legitimate for armed forces to police domestic law within the constitutional and statutory frainework. A closely related question is the definition of the proper legal protections that will apply to the targets of these enforcement activities overseas.

The issue of military law enforcement abroad imphicates many areas of statutory, constitutional, and imternational law, but fits neatly imto none of them. Although some attention has been given to each of these elements im isolation, hittle to no study has been directed toward their interaction. This Note seeks to umite the relevant principles of law to determine under what circumstances such actions may be undertaken to defend the nation's imterests without offending estabhished legal primciples or the rights of individuals. Its scope is necessarily limited to this aim. A complete discussion of potentially relevant issues of extraterritorial jurisdiction alone, for example, would be prohibitive. ${ }^{10}$

This Note argues that the use of military resources abroad can be a legal exercise of enforcement jurisdiction. The nature of most offenses hikely to be enforced in such maimer threatens vital national and imternational interests, and almost by definition will fall outside the reach of conventional means of law enforcement. ${ }^{11}$ However, the government

9. See Regina v. Kear, 51 C.C.C.3d 574 (Can. 1989) (Canadian court held that bondsman had no common law power of surety to arrest absconding defendant outside United States); see also Bruce Zagaris, Mexico Requests Extradition of DEA Agent and a Former Mexican Law Enforcement Official for Kidnapping Dr. Alvarez Machain, 6 INT'L ENFORCEMENT L. REP. 261 (1990).

10. For the sake of its arguments, this Note will assume that the proper prescriptive jurisdiction (power to declare certain conduct outside national borders illegal) exists for whatever offenses are regulated. This is not necessarily always the case, and the presence of prescriptive jurisdiction stands as a threshold issue at all times. The Supreme Court recently reaffirmed that Congress has the authority to prescribe outside American territorial boundaries. See EEOC v. Arabian Am. Oil Co. (ARAMCO), 111 S. Ct. 1227, 1230 (1991). The distinction between prescriptive jurisdiction and enforcement jurisdiction (the power to exercise law enforcement authority) is briefly delineated in REstatement (THIRD) OF THE Foreign RELATIONS LAW OF THE UNITED STATES $\$ 431 \mathrm{~cm}$. a (1986).

11. Criminals within the territory of the United States, of course, could be apprehended by more conventional domestic means of enforcement. At the same tine, those who commit crimes broad enough to threaten national interests often choose to do so from abroad because foreign countries can either knowingly offer a safe haven or are unable to control the actions of those using their 
must ensure that such measures are used only extraordinarily, and only where the situation clearly justifies violations of international comity that may result from the arrest.

Part I outlines relevant provisions of American law that linit use of military force for the enforcenent of civil law and discusses why these laws do not apply overseas or in operations conducted for national security purposes. Part II examines the extent to which the President of the United States may override customary international law principles that prohibit violations of the sovereignty of foreign nations while committing law enforcement actions. Part III considers whether legal guarantees provided by the Constitution or international agreenents can act to invalidate an arrest overseas.

\section{The Posse Comitatus Act: Limitations on Mrlitary Use FOR LAW ENFORCEMENT PURPOSES}

\section{A. Background}

Americans have long maintained a deeply held fear against military mvolvement in civil law enforcement matters. ${ }^{12}$ With the potential for abuse continually underlying the great power of armed forces, civilian control of the military has been firmly established since it was set forth by George Washington early in the nation's history. ${ }^{13}$ Following the Civil War, federal troops in the South took an active role not only in enforcement of numerous civil laws, but also extended the scope of their activity to such egregious activities as interference with the Louisiana State Legislature. ${ }^{14}$

In response, Congress passed the Posse Comitatus Act, ${ }^{15}$ which today prohibits the use of the Army ${ }^{16}$ or Air Force ${ }^{17}$ to enforce the law

territory. The former is exemplified by terrorists operating from Libya; the latter by Colombian narcotics cartels.

12. See James P. O'Shaughnessy, Note, The Posse Comitatus Act: Reconstruction Politics Reconsidered, 13 AM. CR1M. L. REV. 703, 704-05 (1976).

13. See Maurice Matloff, American Military History 16 (1985) (describing the principle as "a fundamental safeguard of republican institutions").

14. O'Shauglinessy, supra note 12 , at 706.

15. Act of June 18, 1878, cli. 263, 20 Stat. 152 (codified at 18 U.S.C. $\S 1385$ (1988)).

16. Although the statute applies on its face to the Army, it does not apply to National Guard units when not in federal service. H.R. CoNF. REP. No. 989, 100th Cong., 2d Sess. 455 (1988), reprinted in 1988 U.S.C.C.A.N. 2503, 2583. National Guard involvement in antidrug efforts has become so pervasive that the Guard lias taken out full-page advertisements in national newspapers to promote it. See USA TODAY, Dec. 31, 1990, at E6 (advertisement picturing troops, lelicopters, and local sheriffs in raid on marijuana field, with text reading: "In 1989, we lelped stop over 12 billion dollars of illegal drugs from reaching our kids.").

Guard involvement now goes as far as patrolling civilian events. See Micliael Isikoff, Interest in Grateful Dead Was Not Musical, WAsH. Post, Aug. 14, 1990, at A4 ("When the Grateful Dead 
"except in cases and under circumstances expressly authorized by the Constitution or Act of Congress." 18 Named after a practice under which county sheriffs could impress citizens to aid in enforceinent of civil authority, the law effectively separates the military from that function. ${ }^{19}$ Although the statutory text does not apply to the $\mathrm{Navy}^{20}$ or Marine Corps, both services have adhered to its provisions as a matter of administrative interpretation. ${ }^{21}$ In addition, amendments clarifying the scope of the statute apply directly to these military branches. ${ }^{22}$ No prohibitions apply to the Coast Guard. ${ }^{23}$

The Posse Coimitatus Act has played an important role in preventmg military interference with civilian affairs. Its enactment had so clearly estabhished the respective spheres of authority that by 1948 the Court of Appeals for the First Circuit, in a now-famous characterization, viewed the Act as an "obscure and all-but-forgotten statute."24

Modern times have significantly comphicated the picture. In some areas, civil law enforcement has proven unable to deal with powerful and

played Foxboro, Mass. last month, the police called in the Massachusetts National Guard... [T] he unusual deployment was a new wrinkle in the [Guard's] escalating antidrug mission.").

17. The Air Force was added to the scope of the statute by technical legislation in 1956 following its absorption of the duties of the Army Air Forces. See Act of Aug. 10, 1956, ch. 1041, § 18(a), 70A Stat. 626 (codified at 18 U.S.C. $\$ 1385$ (1988)).

18. 18 U.S.C. $\S 1385$. More explicitly, the law states that "[w]hoever ... willfully uses any part of the Army or the Air Force as a posse comitatus or otherwise to execute the laws shall be fined not more than $\$ 10,000$ or imprisoned not more than two years, or both." Id.

19. Black's Law Dictionary defines posse comitatus as: "The power or force of the county. The entire population of a county above the age of fifteen, which a sheriff may summon to his assistance in certain cases, as to aid him in keeping the peace, im pursuing and arresting felons, etc." BLACK's LAW DiCTIONARY 1046 (5th ed. 1979).

20. See United States v. Roberts, 779 F.2d 565, 567 (9th Cir.), cert. denied, 479 U.S. 839 (1986).

21. See, e.g., 32 C.F.R. $\$ 213.10$ (c) (1991).

22. See, e.g., 10 U.S.C. $\S 375$ (1988). An excellent analysis of these amendinents points out, however, that they contradict the Posse Comitatus Law in a manner preventing the strict application of this prohibition to the Navy. The limitations in the 1981 and 1988 amendments apply only to the increased powers set forth by those amendments. Because the posse comitatus law itself does not apply on its face to the Navy and Marine Corps, any action outside the scope of those clarifications is presumptively lawful. Paul J. Rice, New Laws and Insights Encircle the Posse Comitatus Act, 104 MIL. L. REV. 109, 126-27 (1984).

23. See United States v. Chaparro-Almeida, 679 F.2d 423, 425 (5th Cir.), cert. denied, 459 U.S. 1156 (1982). In fact, a 1986 amendment to the Posse Comitatus Act specifically requires assignment of Coast Guard personnel to Navy vessels im "drug interdiction areas." See Act of Oct. 27, 1986, Pub. L. No. 99-570, $\S 3053,100$ Stat. 3207, 3207-75 (codified at 10 U.S.C. $\S 379$ (1988)).

24. Chandler v. United States, 171 F.2d 921, 936 (1st Cir. 1948), cert. denied, 336 U.S. 918 (1949). The law did not, in actuality, remain completely dormant. Cases continued irregularly, and a number of rulings interpreting posse comitatus statutes arose from military involvement in Native American uprisings at Wounded Knee. See generally O'Shaughnessy, supra note 12, at 719-30 (detailing history of legal challenges based on posse comitatus laws). 
sophisticated criminal enterprises. In other areas, policymakers have defined criminal offenses that address national security issues rather than matters within the purview of traditional police powers. ${ }^{25}$ Consistent with these changes, Congress in the 1980s began to view military involveinent as a useful tool to suppleinent civilian authority. ${ }^{26}$ The Defense Departinent's reaction at the time was lukewarm, suggesting agreement with critics that it had no role in the area. ${ }^{27}$ Nonetheless, in 1981, Congress enacted detailed clarifications of the Act allowing increased inforination-sharing and other indirect aid. ${ }^{28}$ The law again received clarification and strengthening in $1988 .{ }^{29}$

In the wake of increased activity following these amendinents, posse coinitatus considerations became critical for defendants who were convicted due to assistance provided by the arined services. ${ }^{30}$ In this context, federal courts have umformly declined to find serious or large-scale violations of the Posse Coinitatus Act, ${ }^{31}$ largely as a result of the careful and explicit authority contained in the 1981 and 1988 amendinents $^{32}$ and the relatively low-level nature of current involvement with law enforceinent. ${ }^{33}$

Sending military units abroad with the specific mission of apprehending fugitives poses inore coinplex questions which are largely of first impression. The legality of such a law enforceinent action by the armed

25. See, e.g., 18 U.S.C. \$ 2331 (1988) (criminalizing murder of Americans abroad when undertaken to coerce, intinidate, or retaliate against a government).

26. See, e.g., Posse Comitatus Act: Hearing on H.R. 3519 Before the Subcomm. on Crime of the House Comm. on the Judiciary, 97th Cong., 1st Sess. 1-2 (1981) (statement of Rep. Hughes).

27. See id. at 14-17 (statement of William H. Taft IV, General Counsel of the Department of Defense).

28. Act of Dec. 1, 1981, Pub. L. No. 97-86, 95 Stat. 1114 (codified at 10 U.S.C. §§ 371-378 (1988)).

29. National Defense Authorization Act, Fiscal Year 1989, Pub. L. No. 100-456, 102 Stat. 1918, 2043 (1988) (mandating that military planning consider needs of civilian law enforcement and compelling Defense Department to share imtelligence).

30. See, e.g., United States v. Ahumedo-Avendano, 872 F.2d 367 (11th Cir. 1989) (disınissing complaint alleging violation of Posse Comitatus Act as untimely); United States v. Hartley, 796 F.2d 112 (5th Cir.) (holding that the use of Air Force command and control aircraft to track defendant's plane for civilian authority does not constitute a violation), cert. denied, 479 U.S. 839 (1986).

31. See, e.g., United States v. Roberts, 779 F.2d 565 (9th Cir. 1986) (refusing to apply Act to Navy).

32. The text of the original Posse Comitatus Act allows any civil law enforcement actions specifically approved by Congress. See supra note 18 and accoinpanying text.

33. The degrec of military assistance may be quite significant. See Richard Cheney, Special Defense Department Briefing on National Drug Policy and the Military Role (Sept. 18, 1989) available in LEXIS, Nexis Library, Federal News Service File. The types of aid provided, however, are relatively unobtrusive and unthreatening to civilian interests. The 1981 amendments, for example, authorize sharing of information and intelligence, see 10 U.S.C. $\S 371$ (1988), loan of equipment, see id. §372, and provision of training, see id. §373. 
forces centers around two questions. First, whether the Posse Comitatus Act apphies outside the territory of the Umited States. Second, whether law enforcement undertaken on national security grounds falls outside the statute as a result of either presidential authority in foreign affairs and defense or implied authorization by Congress.

\section{B. The Extraterritorial Scope of Posse Comitatus Prohibitions}

At a broad level, courts, ${ }^{34}$ the executive branch, ${ }^{35}$ and most schol$\operatorname{ars}^{36}$ agree tliat the Posse Comitatus Act does not prohibit extraterritorial arrest by armed forces. Little practical analysis has been undertaken by courts as to the precise rationale for such a limitation. ${ }^{37}$ It seems clear, lowever, that both the statutory text and scope of congressional purpose in enacting tlie law mandate a narrow reading of the law limiting it to American territory.

The language of the Posse Comitatus Act is arguably cast im absolute terms, e.g., "whoever" and "any part of tle Army." By extension, one could argue that tlie law is to reach any action withm its broad definition, wherever it may take place. Basic principles of statutory imterpretation, however, hold that its effect must stop at the border unless explicitly extended by Congress abroad, or the subject matter of the law is inextricably linked to international interests. ${ }^{38}$ Even if the absolutism

34. See United States v. Yunis (Yunis III), 924 F.2d 1086, $1093-94$ (D.C. Cir. 1991).

35. See Isikoff \& Tyler, supra note 6, at A1.

36. See, e.g., Deanne C. Siemer \& Andrew S. Effron, Military Participation in United States Law Enforcement Activities Overseas: The Extraterritorial Effect of the Posse Comitatus Act, 54 ST. JohN's L. Rev. 1, 54 (1979); see also Christopher A. Abel, Note, Not Fit for Sea Duty: The Posse Comitatus Act, The United States Navy, and Federal Law Enforcement at Sea, 31 WM. \& MARY L. REv. 445, 458-59 (1990); John P. Coffey, Note, The Navy's Role in Interdicting Narcotics Traffic: War on Drugs or Ambush on the Constitution?, 75 GEo. L.J. 1947, 1959 n.69 (1987).

37. Authors Sienier and Effron, see supra note 36, provide an exhaustive study of the background and theory precluding extraterritorial application of the Posse Conitatus Act; nuch of this Section is drawn from their scholarship. The broader scope of this Note, however, adds additional considerations that require brief discussion, and calls for an updated and somewhat more practically oriented focus.

38. See United States v. Bownuan, 260 U.S. 94, $98-99$ (1922). Explaining for the Court how such statutes nay be applied abroad, Chief Justice Taft reasoned that "[sone offenses] are such that to linit their locus ... would be greatly to curtail the scope and usefulness of the statute and lcave open a large inınunity for frauds...." Id. at 98 . He continued by posing a rhetorical question: "Is it possible that Congress did not intend by this to include [crines] done aboard ship on the high seas or in a foreign port, where it would be most likely to be done?" Id. at 99.

Generally speaking, statutes will also be applied overseas under principles of extraterritorial jurisdiction when the overseas conduct causes direct effects within the United States. See United States v. Noriega, 746 F. Supp. 1506, 1513-14 (S.D. Fla. 1990). Because the harm in a posse comitatus violation would tend to inure toward the arrested person, who must be arrested abroad even to raise the question of extraterritorial application, it is unlikely that the statute would ever neet this test. 
of the text makes its scope ambiguous, the presumption continues to lie against broad application of the Act overseas witlout clearer legislative guidance. ${ }^{39}$

As a general matter of statutory interpretation, domestic laws do not apply outside the borders of the Umited States unless the text of the law explicitly provides for it. ${ }^{40}$ Chief Justice Taft wrote in United States v. Bowman that "[i]f pumishment . . . is to be extended to include those outside of the strict territorial jurisdiction, it is natural for Congress to say so in the statute, and failure to do so will negative the purpose of Congress in this regard."41 The First Circuit used parallel reasoning in Chandler v. United States ${ }^{42}$ when it declined to invalidate an arrest abroad of a Nazi sympathizer for treason in recording World War II propaganda broadcasts to the United States. ${ }^{43}$

The intended scope of the Posse Comitatus Act also seems to prevent a broad reading of its application. Just as a literal reading of the statutory text seenis to preclude its extraterritorial application, it is also apparent tliat its legislative purpose is limited to military operations withm the Umited States.

Previous works liave exliaustively detailed the formation and listory of the Posse Comitatus Law, ${ }^{44}$ and a lengthy discussion here would be repetitive. It seems largely agreed upon, liowever, that the intent of Congress in approving tlie law was to prevent conflicts witli tlie autliority of civilian officials rather than to sliackle tlie military. Congressman Kimmel, a key participant in the House debate, sumnarized this principle: "If . . the standing Army of the United States can be used as a posse comitatus for the execution of the laws, we are living under a military despotism unqualified and absolute, for what is military despotism but the use of troops agaimst the people without due autliority of the law."45

After studying the entire debate, authors Siemer and Effron wrote that such a principle represented, in large part, tlie consensus of the Congress:

The context of the debate further underscores development of a common theme. Debate focused on opposition to the use of the military in

39. See, eg., Foley Bros. v. Filardo, 336 U.S. 281, 285 (1949).

40. Bowman, 260 U.S. at 98; see also EEOC v. Arabian Am. Oil Co. (ARAMCO), 111 S. Ct. 1227 (1991) (holding that Congress has authority to enforce laws beyond territorial boundaries, but whether it has done so in a particular case is a inatter of statutory construction).

41. Bowman, 260 U.S. at 98.

42. 171 F.2d 921 (1st Cir. 1948), cert. denied, 336 U.S. 918 (1949).

43. See id. at 936.

44. See, e.g., O'Shaughnessy, supra note 12, at 704-10; Siemer \& Effron, supra note 36, at 2445.

45. 7 CoNG. REC. 3582 (1878), cited in Siemer \& Effron, supra note 36, at 27 n.113. 
situations where the organized discipline and tactics of a military force were not required, as for example, in the collection of taxes, service of process, supervision of elections, and in response to labor strife when the task was within the existing or potential capability of state forces .... With respect to extraterritoriality, Congress, in this debate, did not exhibit concern about use of the troops in terms of the President's war powers or otherwise in furtherance of American foreign policy. ${ }^{46}$

As a general matter, military law enforcement abroad would not give rise to the types of conflict envisioned by Congress in its passage of the statute. Because such activities would take place outside the normal reach of conventional law enforcement authorities, there is little danger tliat tlieir powers would be usurped.

Althougli federal courts liave stopped sliort of explicit endorseinent of this interpretation of the law's scope, they liave implicitly adopted the distinction. In United States y. Yunis (Yunis III), 47 tlie Court of Appeals for the District of Columbia Circuit declined to liold tliat extensive use of Navy vessels and aircraft in the apprehension of a Palestinian terrorist hijacker violated the provisions of tlie Posse Comitatus Act. ${ }^{48}$ Yunis was lield aboard a Navy vessel after his apprehension by FBI agents; lie was interrogated there and eventually fiown from a Navy aircraft carrier to federal custody in Washington. ${ }^{49}$ Altlougli the court techincally based the liolding on the exclusion of the Navy from the scope of the Posse Comitatus Act, they also seemed to rely on the fact that the arrest took place abroad. "[C]ourts liave taken the view that the Posse Comitatus Act imposes no restriction on use of American armed forces abroad, noting tliat Congress intended to preclude military intervention in domestic civil affairs."so At a minimum, the Yunis $I I I$ court declined a clear opportunity to repudiate the theory.

Courts liave also seemed to recognize sucli a generally restrictive scope to the application of the statute in their interpretation of wholly

46. Siemer \& Effron, supra note 36 , at $44-45$.

47. 924 F.2d 1086 (D.C. Cir. 1991).

48. See id. at 1093-94.

49. Id. at 1089-90. The Yunis cases collectively address some of the most important contemporary issues in extraterritorial law enforcement. They arise from the case of Fawaz Yunis, a Palestinian terrorist accused of the 1985 hijacking of a Royal Jordanian Airlines jet in Beirut. FBI agents arrested Yunis in international waters off the coast of Cyprus, and transported him to the United States on a Navy warship. The first case, United States v. Yunis (Yunis I), 859 F.2d 953 (D.C. Cir. 1988), examined claims made by Yunis under the Bill of Rights. The second case, United States v. Yunis (Yunis II), 867 F.2d 617 (D.C. Cir 1989), concerned slightly more routine issues surrounding discovery of classified information. The Yunis III case examines a number of diverse issues of prescriptive and enforcement jurisdiction surrounding Yunis's seizure abroad.

50. Yunis III, 924 F.2d at 1093 (citing Chandler v. United States, 171 F.2d 921, 936 (1st Cir. 1948), cert. denied, 336 U.S. 918 (1949) and D'Aquino v. United States, 192 F.2d 338, 351 (9th Cir. 1951), cert. denied, 343 U.S. 935 (1952)). 
domestic cases. Instead of insisting upon rigid separation, the law requires a high threshold of military imtervention prior to finding a violation. In United States v. Casper, ${ }^{51}$ the Court of Appeals for the Eighth Circuit adopted the district court's efforts to formulate a coherent test: "Were the Army or Air Force personnel used by the civilian law enforcement officers ... in such inanner that the military personnel subjected the citizens to the exercise of military power which was regulatory, proscriptive, or compulsory in nature, either presently or prospectively?"52

This test provides wide latitude for military involvement in law enforcement even within the Umited States. The Casper opinion dealt with the provision of mdirect assistance ${ }^{53}$ to civilian authorities by military forces acting under civil supervision. It is particularly noteworthy that the decision came prior to the passage of the 1981 and 1988 amendments, which gave exphicit congressional approval for such imdirect aid. The court's test, then, can be construed as a common law adoption of the idea that the Posse Connitatus Act apphies only where the armed forces actually exert authority that should properly belong in civilian hands. ${ }^{54}$

When translated to a scenario that involves extraterritorial enforcement, one element of the Eighth Circuit holding nonetheless seems at first to preclude large-scale involvement of the military. In Casper, the court mdicated that the actual exercise of compulsory power by the military would constitute a violation of the Posse Comitatus Law. ${ }^{55}$ Any direct involvement by armed forces abroad would definitionally fail this test. If their intervention proved necessary to enforce the laws, the military would always act to compel the arrested persons to return to the Umited States for trial.

51. 541 F.2d 1275 (8th Cir. 1976), cert. denied, 430 U.S. 970 (1977).

52. Id. at 1278 (citing United States v. McArthur, 419 F. Supp. 186, 194 (D.N.D. 1975), aff'd sub nom. United States v. Casper, 541 F.2d 1275 (8th Cir. 1976), cert. denied, 430 U.S. 970 (1977)).

53. The Casper case was one of a series of cases stemming from Native American uprisings at Wounded Knee, South Dakota. Civilian law enforcement authorities used niaterial and equipment provided by the Army and the South Dakota National Guard. Army personnel also acted as observers and advisors, conducted aerial reconnaissance, and prepared contingency plans for full-scale intervention to retake the occupied reservation should the civilian efforts have proven inadequate. See United States v. Red Feather, 392 F. Supp. 916, 921 (D.S.D. 1979).

54. The court found that no such conflict took place, and dechined to find a violation. Casper, 541 F.2d at 1278. For a case where the military overstepped its bounds, see United States v. Walden, 490 F.2d 372 (4th Cir.), cert. denied, 416 U.S. 983 (1974) (holding that participation of military officer as undercover agent in civil operation is impermissible).

Another analysis characterizes the Red Feather distinction as an active/passive test. See Rice, supra note 22, at 116. This approach is important in describing the bounds of permissible military activity but is not instrnctive in the extraterritorial context. The active/passive distinction only partially describes the legislative intent from which it stenis and does not address the importance of conflicting authority in finding a violation.

55. See Casper, 541 F.2d at 1278. 
It is critical to remember, however, that Casper arose within the context of a domestic enforcement action. If the test is seen as an endorsement of the theory that the Act only apphies where there is an actual conflict with civil authority, the compulsion element of it will not apply outside the United States. In most cases, it is the precise fact that other methods are unavailing that leads to the introduction of the military as a means of enforcement. There is accordingly no conflict with the established powers of civil authorities that would contravene the purpose of the Posse Comitatus Act. Presurnably, the prescriptive and regulatory elements would remain intact, as civil authorities retain broad discretion to extend abroad the reach of their powers in these areas. ${ }^{56}$

Understanding the overall scope of the Posse Comitatus Act remains a comphicated and sometimes highly techirical undertaking. ${ }^{57}$ The propriety of Defense Department assistance to civil authorities often hinges on minute details that make doinestic imterpretation of the law something of an art form. Outside of national borders, however, no conflict arises with the jurisdiction of American civil authorities sufficient to counter the text or purpose of the law.

\section{Law Enforcement Exempted from the Statute}

Even if an extraterritorial arrest is construed to conflict with the Act's basic text and purpose, it is permissible where undertaken as an explicit extension of authority of the political branches of government. The Posse Comitatus Act defines two classes of law enforcement by the armed forces that are permissible even where the law would otherwise prohibit it: those authorized by the Constitution; and those approved by Congress.

1. Constitutional Powers of the Executive. An elementary tenet of statutory interpretation holds that courts must construe statutes to avoid conflicts witl the Constitution. ${ }^{58}$ To interpret the scope of the Posse Comitatus Act broadly in cases containing national security elements

56. Yunis III, 924 F.2d at 1090.

57. Although the 1981 and 1988 amendments have added much-needed clarity to the field, the increased use of military resources to combat narcotics trafficking within U.S. territory has continued to fuel a wide-ranging debate surrounding the question of which military activities are appropriate within the United States. See generally Roger B. Hohnsbeen, Note, Fourth Amendment and Posse Comitatus Act Restrictions on Military Involvement in Civil Law Enforcement, 54 GEO. WASH. L. REv. 404 (1986) (noting the tension between civilian control of the military and military law enforcement).

58. See, eg., McCullough v. Virginia, 172 U.S. 102, 112 (1898) ("It is elementary law that every statute is to be read in the light of the Constitution. However broad and general its language, it cannot be interpreted as extending beyond those matters which it was within the constitutional power of the legislature to reach."). 
would raise serious conflicts with the deference given to the executive branch in military affairs. ${ }^{59}$ To address this concern, the Act explicitly exeinpts constitutionally authorized actions froin its operation-a savings clause designed to avoid conflicts with the enuinerated powers of the executive. ${ }^{60}$

Because federal courts have decided the few extraterritoriahty cases before them under an analysis of the general scope of the statute, the exeinptions contained within it have received little examination. If a law enforcement action is predominantly justified by the executive branch on foreign policy grounds, it may be characterized as a legal extension of that power rather than a violation of congressional regulation in the Posse Coinitatus Act. ${ }^{61}$

Despite the Constitutional predominance of the executive branch, Congress inay indirectly regnlate many aspects of foreign affairs and defense policies under its emunerated legislative powers. Although it has hittle say over day-to-day pohcy, the appropriations power provides a potent weapon to control broad classes of executive conduct of which the legislature disapproves. ${ }^{62}$ In addition, the emunerated powers to "raise and support armies" and to "make Rules for the Government and Regulation of the land and Naval forces"63 allow the legislature to retain a broad general discretion over the use of the military. ${ }^{64}$

In a national security context, the Posse Comitatus Act straddles the border between the executive and legislative powers. The President has broad authority to deal with international crises. Congress inay generally regulate the manner in which this power is used, but inay not interfere with the ongoing exercise of discretion. The distinction between

59. See, e.g., United States v. Pink, 315 U.S. 203 (1942) (noting the broad discretion granted to the executive branch); Kendall v. United States ex rel. Stokes, 37 U.S. (12 Pet.) 524, 610 (1838) ("The executive power is vested in a President; and as far as his powers are derived fron the constitution, he is beyond the reach of any other departnient . . . ."); EDWARD S. CoRwin, The PRES1DENT: OFFICE AND Powers, 1787-1957, at 198-201 (1957).

60. See supra note 18 and accompanying text.

61. Chandler v. United States, 171 F.2d 921, 936 (1st Cir. 1948) ("It would be unwarranted to assume that such a statute was intended to be applicable to occupied enemy territory, where the inilitary power was in control . . ."), cert. denied, 336 U.S. 918 (1949).

62. The 1988-1989 Foreign Relations Authorization Act, Pub. L. No. 100-204, 101 Stat. 1331 (1987), for example, contained myriad amendments limiting State Department spending as a means to guide policy. For exanuple, the Department was ordered to close diplomatic posts in Antigua and Barbuda, see id. $\S 123,101$ Stat. at 1341 , and has been given guidance on the protection of the rights of Hungarians in Transylvania, see id. $\S 1205,101$ Stat. at 1411.

63. U.S. CoNST. art. $1, \S 8$, cls. $12,14$.

64. The House Armed Services Conimittee, for example, defines its jurisdiction first and forenoost in the extremely vague terms of "[c]ommon defense generally." RULES OF THE HOUSE OF REPRESENTATIVES Rule X, cl. 1(c)(1). 
the two is subtle and somewhat difficult to determine with precision. ${ }^{65}$ Although a hypothetical use of the military abroad for law enforcement purposes would be generally authorized by the executive power, it is far less certain that it would be permissible if Congress had prohibited that class of operation in advance.

The problem is not a new one; congressional guidance of executive decisionmaking is an everyday phenomenon. ${ }^{66}$ Reaching a final solution to the question is problematic, because it quickly degenerates into an issue of circular reasoning. ${ }^{67}$ The executive is free to use armed forces as an extension of its power, as long as Congress has not legitimately exercised its own option to prohibit such use. Under the Posse Comitatus Act, the face of the text passed by Congress would apply to prohibit a military law enforcement action as long as it does not contravene the prerogatives reserved to the executive. ${ }^{68}$ To make matters worse, the dividing line between the powers of the two branches is hazy.

This hazmess makes the status of the constitutional exception uncertam. In theory, the analysis ultimately depends on how broadly the scope of the statute is viewed. The Posse Comitatus Act is a valid exertion of the legislative power to regulate the appropriate use of armed forces. In effect, it facially prohibits use of the military for a certain type of operation much like other clauses in authorization and appropriations bills. Because Congress has registered objection to deployments falling within the law, the constitutional authority of the executive is severely diminished. ${ }^{69}$ If the Posse Comitatus Act is viewed as an absolute prohibition on military arrest, the savings clause in theory leaves little room on its face for such operations, barring an emergency. ${ }^{70}$ In practice, however, the law is narrowly viewed to protect ouly domestic civil authority.

65. Such difficulties are not unique to the context of foreign affairs, although much rarer there. The distinction reflects a structural tension inhereut in the Constitution. In adninistrative law, for example, congressional interference often may conflict with executive rulemaking. See, e.g., D.C. Fed'n of Civic Ass'ns v. Volpe, 459 F.2d 1231 (D.C. Cir. 1972).

66. See Sienter \& Effron, supra note 36, at 17-18. The article sees potential application of the statute as a linitation ou executive authority raising "substantial constitutional questions," but says little about the countervailing authority of the Congress. It is perhaps worth noting that the authors of that article were employed at the time of its publication by the Departnents of Energy and De-

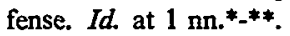

67. Justice Jackson sunmarized the conflict between the President and Congress in his concurring opinion in Youngstown Sheet \& Tube Co. v. Sawyer, 343 U.S. 579 (1952) (The Steel Seizure Case): "A century and a half of partisan debate and scholarly speculation yields no net result but only supplies more or less apt quotations front respected sources on each side of any question. They largely cancel each other." Id. at 634-35 (Jackson, J., concurring).

68. Although, as a reninder, it ouly has force within its scope of applicability.

69. See The Steel Seizure Case, 343 U.S. at 637 (Jackson, J., concurring).

70. The Prize Cases, 67 U.S. (2 Black) 635 (1862), recognize increased deference to executive authority in energency situations. 
Because the scope of the statute does not seem to contemplate its operation abroad, the President must imphicitly retain his power in that area.

2. Authorization by Congress. Under the second statutory exemption, Congress itself has a strong say in what actions may be permissible. The Posse Comitatus Act exempts from its terms operations "expressly authorized . . . by Act of Congress."71 If Congress approves of any law enforcement activity by the military, foreign or domestic, it is not proscribed by the Act.

This exemption can be an important source of authority for a President who wishes to use the military for law enforcement purposes. In examining previous foreign relations questions, federal courts have shown a willingness to infer congressional approval from almost any sort of acquiescence in the actions of the executive. ${ }^{72}$ By extension, such support for the actions of the President give a nearly insurmountable constitutional authority at the "maximum" of foreign relations power. ${ }^{73}$

Even silence can imply a limited form of consent. ${ }^{74}$ The textual demand for express authorization, however, requires a more affirmative action on the part of Congress. Just as the multitude of statutes that they must pass simply to fund the Defense Department allows the House and Senate to impose many of its views upon the executive, Congress also must bear a much greater share of the responsibility for what takes place under its nominal direct supervision. Funding for an action constitutes a form of both explicit and imphicit congressional approval for the action. ${ }^{75}$ Technically, an appropriation is an "Act of Congress" and implicit approval through funding might serve to satisfy the requirements of the statutory exemption.

Presidential power would be particularly strong where an international enforcement action came in the course of a long-term policy developed in consultation with the legislative branch. Military involvement in coinbating narcotics trafficking is a powerful example. The Congress has

71. Posse Comitatus Act, 18 U.S.C. $\$ 1385$ (1988).

72. See, e.g., The Steel Seizure Case, 343 U.S. at 637 (Jackson, J., concurring) (arguing that "congressional inertia, indifference or quiescence" can allow the President to act alone); Holtzman v. Schlesinger, 484 F.2d 1307, 1313-14 (2d Cir. 1973) (implicit congressional authorization of Vietnain War), cert. denied, 416 U.S. 936 (1974).

73. See The Steel Seizure Case, 343 U.S. at 635 (Jackson, J., concurring).

74. See id. at 637.

75. See, e.g., Orlando v. Laird, 443 F.2d 1039 (2d Cir.), cert. denied, 404 U.S. 869 (1971). In considering whether Congress had delegated warmaking power to the executive branch during the Vietnam war, the court found implied delegation sufficient. "[A]ppellants . . . argue that congressional authorization cannot, as a matter of law, be inferred froin military appropriations or other war-inplementing legislation that does not contain an express and explicit authorization for the Inaking of war by the President. ... [W] disagree with appellants' interpretation ...." Id. at 1043. 
made clear its desire that the military take on mcreased involvement in countering drug smuggling activities on the border and commanded them to assume a number of specific tasks. The 1981 and 1988 amendinents to the Posse Comitatus Act were designed to support this effort. ${ }^{76}$ Even without such specialized authority, however, the executive could offer a very strong case to support the proposition that Congress had acquiesced in almost any action that could be considered even rationally related to those goals.

Although less powerful, many other types of legislation could fortify the hand of the President. One justification offered by the United States in support of its invasion of Panama was protection of the Panama Canal. ${ }^{77}$ Congress has often provided for defense of the Canal. ${ }^{78}$ Further, it expressed the sense of Congress that the drug-related indictment of Manuel Noriega reached the level of a national security interest. ${ }^{79}$ By extension, the Panama action could easily be defended as a natural consequence of this approved policy.

As a whole, the two statutory exemptions seein to give the President tremendous leeway to use the military abroad, even for a potential law enforceinent purpose. If the action is related to an ongoing policy supported by Congress, it potentially may be defended as authorized by the legislature and exeinpt from Posse Comitatus considerations. If the military is used to ineet a more immediate threat, the executive could justify its action under its constitutional authority. Either way, Congress unust effectively raise an explicit objection to prevent use of the armed forces to enforce laws overseas.

Although not completely ineaningless, the Posse Comitatus Act seems to be of greatly reduced concern in an international context. Within the framework of American statutory law, it is proper for the President to use the military to enforce doinestic laws abroad as long as the action does not conflict with the reach of civilian authority. Even if there is such a conflict, use inay be permissible if the action is explicitly

76. See, eg., National Defense Authorization Act, Fiscal Year 1989, Pub. L. No. 100-456, 102 Stat. 1918, 2047-49 (1988) (Title XI-"Drug Interdiction and Law Enforcement Support").

77. See Marian N. Leich, Digest of U.S. Practice in International Law, 84 AM. J. INT'L L. 545, 545-46 (1990).

78. See, e.g., National Defense Authorization Act, Fiscal Year 1989, § 1301, 102 Stat. at 205960. Section 1301 declares the operations of the U.S. Southern Command to protect the free flow of shipping through the Canal as vital to U.S. security interests. Id.

79. Section 1303 of the act in fact might be construed to have licensed the Bush Administration to hunt down Noriega, expressing the sense of Congress that no negotiations should be undertaken with Noriega to drop the drug indictments then pending, and that to do so would not serve the national security interests of the United States. See National Defense Authorization Act, Fiscal Year 1989, § 1303, 104 Stat. at 2060-61. 
approved by Congress or undertaken on an emergency basis by the President. From a strictly operational standpoint, American domestic law permits law enforcement by the military.

\section{The Rapidly EXPANDing Reach of AMERICAN ENFORCEMENT JURISDICTION ABROAD}

Even the most expansive imterpretation of executive authority to enforce national laws overseas would ultimately prove meaningless if American enforcers had no jurisdiction to do so outside of the country. Although it is well settled that conduct may be regulated abroad, scrupulous deference to principles of international comity and national sovereignty have circumscribed the abihty of authorities to act upon violations. ${ }^{80}$ As recently as 1980, the Carter Administration had explicitly denied authority for law enforcement overseas. ${ }^{81}$

Rapid geopohitical changes have forced the American government to reevaluate carefully these policies as other nations have proven unwilling or unable to deal with challenges to it within their territories. ${ }^{82}$ As a result, the Umited States has demonstrated an increasing willingness to extend the reach of its law enforcement in foreign countries. The executive branch now believes that it is a legitimate extension of presidential authority under the Constitution for the Federal Bureau of Investigation (FBI) and U.S. military to make arrests on foreigu soil, even without the consent of the host government. ${ }^{83}$

For such an expanded theory of jurisdiction to have practical meaning, it must at a minimum prove justifiable under American domestic law. An arrest is meaningless if federal courts hold that it is itself illegal and unenforceable. ${ }^{84}$ To the extent that notions of public international law commanding respect for state sovereiguty are incorporated into domestic law, they preclude arrest abroad. The current policy is noteworthy because it recognizes that American law does not in fact command such absolute respect for territorial sovereignty - an interpretation amply supported by precedent.

80. See, e.g. , FTC v. Compagnie De Saint-Gobain-Pont-a-Mousson, 636 F.2d 1300, 1304 (D.C. Cir. 1980) (notimg that principles of comity may prevent domestic courts from taking actions offending foreign nations).

81. See Extraterritorial Apprehension by the Federal Bureau of Investigation, 4B Op. Off. Legal Counsel 543 (1980).

82. See, e.g., Cornwell, supra note 2 , at 13 (accused terrorists harbored in Libya).

83. See Marcus, supra note 6, at A72; Isikoff \& Tyler, supra note 6, at A1.

84. See United States v. Verdugo-Urquidez, 939 F.2d 1341 (9th Cir. 1991); United States v. Caro-Quintero, 745 F. Supp. 599 (C.D. Cal. 1990), aff'd sub nom. United States v. AlvarezMachain, 946 F.2d 1466 (9th Cir. 1991), cert. granted, 116 S. Ct. 857 (1992). 


\section{A. Past and Present Perspectives}

The changes in prominence and principle behind the issue of extraterritorial arrest did not so much evolve as explode. In October 1989, the media reported that the Justice Departinent's Office of Legal Counsel had provided to first the FBI and then the military what colloquially became known as "the president's snatch authority". ${ }^{85}$ The FBI authority came in a legal opinion reportedly prepared that June under the supervision of Assistant Attorney General William P. Barr at the request of Attorney General Richard Thornburgh. ${ }^{86}$ This opinion largely dealt with executive authority to take actions inconsistent with public international law. In Noveinber, a second opinion followed, effectively approving extraterritorial arrest powers for the military, based largely on posse coinitatus considerations. ${ }^{87}$ A month later, American troops were scouring Panama atteinpting to arrest General Manuel Noriega. ${ }^{88}$

The legal analysis in the FBI opinion is important in the military context because potential military arrest operations involve the same issues of state sovereignty. In substance, this opinion only differs in one respect from the longstanding policies that had preceded it. The change, however, was critical. Instead of deferring to the sovereignty and sensibilities of foreign nations, the needs of doinestic law and the American national interest could now take equal or greater precedence. The exact contents of both opinions remam confidential within the Justice Department and have not been released to the public. It is possible, however, to piece together enough of the substance of the policy from public sources to provide a general analysis of its legal reasoning.

After the initial newspaper reports on the FBI opinion, Barr and State Department Legal Adviser Abraham Sofaer appeared before the Subcoininittee on Civil and Constitutional Rights of the House Judiciary

85. See Ronald J. Ostrow, FBI Gets OK for Overseas Arrests, L.A. TIMES, Oct. 13, 1989, at A1.

86. Id. At the time, Barr headed the Office of Legal Counsel; in the fall of 1991, he was appoiuted Attomey General.

87. See Isikoff \& Tyler, supra note 6, at A1. The Los Angeles Times reported:

Barr's opinion reviews the history of the 1878 Posse Comitatus Act, passed in response to opposition to military oversight of Reconstruction Era elections. The ruling concludes that the act sought to bar military interference in functions of the states and was not meant to address military actions in other countries, an Adininistration official said.

"All the legislative history (of the act) related to interference with the states, with the military iu conflict with Americans that could undermine confidence in the military," he said. "It was not Congress' intent for it to apply extraterritorially."

Ronald Ostrow, Ruling Backs U.S. Forces' Police Role, L.A. TimEs, Dec. 17, 1989, at A1.

88. Two months earlier, an Army Special Forces team had allegedly been prepared to apprehend Colombian narcotics cartel leader Pablo Escobar, who had been reported in Panama. The Escobar sighting later proved to be erroneous. Isikoff \& Tyler, supra note 6, at A1. 
Committee to explain its legal reasoning. ${ }^{89}$ Barr told the committee that the opinion represented a change in only the Administration's interpretation of U.S. law, and not a fundamental change in overall national policy regardmg the territorial integrity of other nations. The result was to be interpreted as a statement of "the domestic legal authority to make such [extraterritorial] arrests." 90

The thrust of the idea is simple. Within the American legal system proper, there is no limit to the scope in which its own provisions may be enforced. The proposition in some respects is so simple as to be misleading. At a minimum, soine form of external restraint inust be incorporated within that legal system to govern its relations with other legal systems. It is disingenuous to consider doinestic law in isolation when the very nature of the issue requires consideration within a greater scope. The question addressed by the Justice Departinent inore properly should be viewed as an analysis of when it is appropriate to override these considerations of comity.

Respect for sovereign interests of foreign nations is usually incorporated into American law as respect for international comity. Where law enforcement officers exercise their functions abroad without the consent of the appropriate officials in the foreign state, the arrest in theory violates state sovereignty and customary international law. ${ }^{91}$ Such an action is only wholly justifiable within the international realm where the asylum state inakes no protest of the arrest. ${ }^{92}$

The Carter Justice Department in 1980 recognized sovereign concerns as the cornerstone of its prohibition on enforcement activities abroad. Its legal opimion caine in response to an FBI plan to apprehend fugitive financier Robert Vesco in the Bahamas, despite the refusal of the

89. See FBI Authority to Seize Suspects Abroad: Hearing Before the Subcomm. on Civil and Constitutional Rights of the House Judiciary Comm., 101st Cong., 1st Sess. 2-42 (1989) (statements of William P. Barr and Abraham D. Sofaer) [hereinafter Seizure Hearing].

90. Id. at 26 (statement of Abraham D. Sofaer, State Department Legal Adviser) (emphasis added).

91. See Restatement (THIRD) OF THE Foreign Relations LaW OF THE UNITEd States $\S 432$ (2) (1986). Comment b to section 432 explains: "It is universally recognized, as a corollary of state sovereignty, that officials of one state may not exercise their functions in the territory of another state without the latter's consent." Id. $\S 432 \mathrm{cmt}$. b.

92. Id. $\$ 432$ reporter's note 2 (noting rule of "male captus, bene detentus"). This Note assumes throughout that the asylum state will protest extraterritorial arrest in its territory. In the absence of such protest, comity is presumed not to be offended despite the presence of a technical violation of state sovereignty. 
Bahamian government to grant its consent to the arrest.93 "[W]e conclude that the FBI only has lawful authority when the asylum state acquiesces to the proposed operation. Since we are to assume that a pro forma protest to the operation wonld be filed that fundamental condition would probably not be satisfied here."94 The opinion relied not on domestic law, but on an incorporation of imternational legal principles.

In sum, asylum state consent appears pivotal to the success of the operation, both as a matter of litigation and public perception ....

In the current international climate, this country can ill afford an operation that would permit others to argue that the United States does not respect international law. We advise you not to authorize the operation without the asylum state's tacit consent. 95

The Carter Admimistration opinion would thus grant almost complete deference to foreign governments in enforcement matters taking place within their territories. Such great deference, however, is inconsistent with the more limited role that international considerations have been given under American law in the face of countervailing domestic interests.

The Bush Adininistration opinion, like that of the Carter Justice Department, views policy considerations as central to consideration of extraterritorial arrest issues. The 1989 opinion, however, stops short of casting sovereign concerns as an inipenetrable legal standard, instead leaving policy determinations in the hands of policymakers. This reading of the law relies on the fact that comity stands, at best, as customary international law within the domestic arena. ${ }^{96}$ In a scenario involving military law enforcement, those rules can be truinped by the explicit constitutional powers of the President as commander in chief. ${ }^{97}$

According to Barr, the Bush Administration reexammed the 1980 Office of Legal Counsel opinion in light of the perception that criminal and terrorist organizations had begun operating with relative impunity from offshore foreign sanctuaries. "While many nations have cooperated in our efforts ... by entermg into extradition agreeinents and providing

93. Vesco was "accused of looting hundreds of millions of dollars from mutual funds before fleeing to Central America in 1973. He also [was] charged with secretly giving $\$ 200,000$ to former President Richard Nixon's 1972 reeleetion campaign to try to obstruct an investigation by the Securities and Exchange Commission." Ostrow, supra note 85, at A1.

94. Extraterritorial Apprehension by the Federal Bureau of Investigation, 4B Op. Off. Legal Counsel 543, 544 (1980).

95. Id. at 556.

96. See RESTATEMENT (THIRD) OF THE Foreign RELATIONS LaW of THE UNITEd States $\S 101 \mathrm{cmt}$. e (1986) (discussing comity); id. $\S 111 \mathrm{cmt}$. $\mathrm{c}$ (discussing status of international law in domestic law).

97. See U.S. ConsT. art. II, § 2. 
us with other forms of assistance, some foreign governments have unfortunately failed to take steps to protect the Umited States from these predations, and others actually act in complicity with these groups."98

The resulting opinion draws heavily upon the preeminence of the President's constitutional authority, echoing the inportance of the concept in making law enforcement actions permissible under the Posse Comitatus Act. ${ }^{99}$ This authority is especially pronounced where several areas of executive control intersect-in this case, in the fields of foreign affairs, defense, and law enforcement. ${ }^{100}$ Along those lines, the Office of Legal Counsel now contends that "the executive and legislative branches, acting within the scope of their respective authority, may take or direct actions which depart from customary international law." 101 The contention has techuncal merit because international law only has legal force in the United States insofar as it is not superseded by actions of the political branches. ${ }^{102}$ Without recognition of controlling domestic acts, the United States would be unable itself to contribute to the formation of norms of customary law.

For additional support, the Justice Departinent cited two judicial cornerstones of executive power. In the national security field, the opinion relied on Justice Jackson's concurrence in The Steel Seizure Case, which stated that courts "should indulge the widest latitude of interpretation to sustain [the President's] executive function to command the instruments of national force, at least when turned against the outside world for the security of our society." 103 For inherent law enforcement power, the Office of Legal Counsel analysis cited In re Neagle. ${ }^{104}$

To make its ultimate point that this power can override customary imternational norms, Barr's testimony finally noted the decision of the Court of Appeals for the Eleventh Circuit in Garcia-Mir v. Meese. ${ }^{105}$

98. Seizure Hearing, supra note 89, at 9 (statement of William P. Barr, Assistant Attorney General, Office of Legal Counsel).

99. See id. at 12.

100. See id. at 16.

101. Id. at 14.

102. See The Paquete Habana, 175 U.S. 677, 700 (1900) (holding that "controlling executive or legislative act[s]" may supplant legal norms of customary international law).

103. Youngstown Sheet \& Tube Co. v. Sawyer, 343 U.S. 579, 645 (1952) (The Steel Seizure Case) (Jackson, J., concurring).

104. 135 U.S. 1 (1890). In re Neagle held that the executive branch did not require explicit statutory authority in pursuit of its duty to faithfully execute the nation's laws. The Barr statement quoted Justice Miller's opinion, which held that that authority extended to the "rights, duties, and obligations growing out of the Constitution itself, our imternational relations, and all the protection implied by the nature of the government under the Constitution." Seizure Hearing, supra note 89, at 6 (quoting In re Neagle, 135 U.S. at 17).

105. 788 F.2d 1446 (11th Cir.), cert. denied, 479 U.S. 889 (1986). 
Garcia-Mir arose from a challenge to the detention of Cuban aliens arriving in the Mariel boatlift. The court agreed that the executive could lawfully take actions that might be inconsistent with public international law when exercismg constitutional authority. ${ }^{106}$

Whatever distaste opponents of extraterritorial arrest may have for its use as a tool of foreign policy, the Justice Department argues that it is not in itself illegal in the overall scheme of American law. Under this logic, the outweighed demands of international law become prudential constraints on the developinent of policy to use presidential authority. Because the consequences of a breach of comity will fall to it to remedy in the political arena, the executive should be free to determine its own course of action. Barr explamed the overall position:

[W] hen the President is making a decision in the area of extraterritorial law enforcement, we have the intersection of a number of responsibilities. He acts as the foremost law enforcement officer in the country. He acts as the administrator of the foreign relations of the United States and as Commander in Chief. He has a range of responsibilities, mcluding the responsibility to take into account international law and the international obhigations of the United States. ...

But when push comes to shove, after he has weighed all of those factors, and he determines that it is in the national interest to pursue a particular law enforcement operation overseas, that judgment, as a matter of domestic law, overrides customary international law, and that is an authorized, legal, constitutional action for American agents to engage in.

At the same time, it is a violation, or under many circumstances it could be a violation of international law, and we would have to be prepared to take the consequences of that violation. ${ }^{107}$

\section{B. Presidential Authority to Override Customary International Law}

The opinion froin the Bush Justice Department received a great deal of attention-largely because the authority to override nominal considerations of comity to serve American national interests is sparse in the criminal context. The position that sovereignty is not an absolute bar to executive action has much stronger support in judicial precedent, however, than contemporary wisdom may recognize. ${ }^{108}$ The point has not

106. See id. at 1454-55.

107. Seizure Hearing, supra note 89 , at 61.

108. The principle is begrudgingly acknowledged in the Restatement. See RESTATEMENT (THIRD) OF THE FOREIGN RELATIONS LAW OF THE UNITED STATES § 115 reporter's note 3 (1986) ("There is authority for the view that the President has the power, when acting within his constitutional authority, to disregard a rule of international law ... notwithstanding that international law and agreements are law of the United States...."). 
only been long recognized in American law, but has also been broadly applied in diverse cases that allege violations of international law.

As far back as 1815, Chief Justice Marshall wrote on the issue of extraterritorial apprehension in The Ship Richmond $v$. United States:109

The seizure ... within the territorial jurisdiction of a foreign power is certainly an offence against that power, which must be adjusted between the two governments. This court can take no cognizance of it; and the majority of the court is of opinion that the law does not connect that trespass, if it be one, with the subsequent seizure by the civil authority ... so as to annul the proceedings of that court. ${ }^{110}$

The theine returned in the classic rendition case Ker v. Illinois, ${ }^{111}$ which held that seizure of a criminal suspect in Peru without the consent of the Peruvian government could not affect the defendant's status in American courts because, in effect, no doinestic laws had been violated. ${ }^{112}$ The case recognized, however, that such a seizure could have important ramifications on international affairs and, again, viewed it as an issue committed largely to the executive branch:

It must be remembered that this view of the subject does not leave the prisoner or the government of Peru without remedy for his unauthorized seizure within its territory. [A treaty] with that country provides for the extradition of persons charged with kidnapping, and on demand from Peru, Julian, the party who is guilty of it, could be surrendered and tried in its courts for this violation of its laws. ${ }^{113}$

Altlough Garcia-Mir remains the main contenporary case regarding presidential authority, the principle was recognized with equal strength in United States v. Yunis (Yunis III): ${ }^{114}$

Whatever inerit appellant's clann may have as a matter of interuational law, they cannot prevail before this court. Yunis seeks to portray international law as a self-executing code that trumps domestic law whenever the two conflict. That effort misconceives the role of judges as appliers of international law and as participants in the federal system. Our duty is to enforce the Constitution, laws, and treaties of

109. 13 U.S. (9 Cranch) 102 (1815).

110. Id. at 104.

111. 119 U.S. 436 (1886).

112. In his opinion, Justice Miller seemed to have difficulty even finding an articulation of the legal arguments that Ker had attempted to make against the seizure.

The question of how far his forcible seizure in another country, and transfer by violence, force, or fraud, to this country, could be niade available to resist trial in the State court ... is one which we do not feel called upon to decide, for in that transaction we do not see that the Constitution, or laws, or treaties of the United States guarantee him any protection.

Id. at 444.

113. Id. Indeed, this exact remedy has been sought by foreign countries in modern times. See, e.g., Zagaris, supra note 9, at 261 (reporting that the Mexiean government sought extradition of a DEA agent involved in an extraterritorial arrest).

114. 924 F.2d 1086 (D.C. Cir. 1991). 
the United States, not to conform the law of the land to norms of customary international law. ${ }^{115}$

Authority to override customary international law is so readily inferred that courts have not limited the principle solely to the President. Congressional action in pursuit of the constitutional duties of the legislative branch also will be deemed sufficient to trump international norins. In Committee of United States Citizens Living in Nicaragua v. Reagan, ${ }^{116}$ the Court of Appeals for the District of Columbia Circuit held that no enactment of Congress could be challenged on the ground that it violates customary law, even as set forth by the International Court of Justice:

[T] he key question is not simply whether the United States has violated [international legal norms] but whether such violations can be reinedied by an American court or whether they can only be redressed on an international level. In short, do violations of international law have domestic legal consequences? The answer largely depends on what form the "violation" takes. ... The answer is "no" if the type of international obligation that Congress and the President violate is either a treaty or a rule of customary international law. ${ }^{117}$

These opinions still seem somewhat unsatisfactory because they do not readily explain why customary international law is effectively thrown out of the equation despite its incorporation into American law. ${ }^{118}$ Contemporary courts hoping to reform the basic doctrine of The Ship Richmond on these grounds, however, should tread carefully. The most abundant contemporary source of precedent in conflict with foreign legal systems sensitive to their own prerogatives are cases that involve extensions of the power of American courts im civil litigation. Like cases imvolving the political branches, these decisions ultimately reduce to pragmatism rather than consistent exercise of theory.

American courts have usually declined to give a preeminent role to considerations of coinity with foreign law where the main questions of fact or law are American or the main effect of the questioned act falls upon the Umited States, despite possible affront to other nations. Foreign legal systems witl more centralized and authoritarian views of judicial power, for exainple, often view service of process by American lawyers

115. Id. at 1091 .

116. 859 F.2d 929 (D.C. Cir. 1988). Reagan concerned a challenge to congressional appropriation of funds for the Nicaraguan contras.

117. Id. at 935 .

118. Extensive debate on the theoretical aspects of executive branch authority to conduct action inconsistent with international law may be found in Jonathan Charney, The Power of the Executive Branch of the United States Government to Violate Customary International Law, 80 AM. J. INT'L. L. 913 (1986); Michael Glennon, Can the President Do No Wrongs?, 80 AM. J. INT'L. L. 923 (1986); Louis Henkin, The President and International Law, 80 AM. J. INT'L L. 930 (1986). 
within their nations as offensive to national sovereignty. ${ }^{119}$ Under the domestic laws of these nations, the actions are not only invalid, but can be grounds for diplomatic protest. ${ }^{120}$ Under a strict incorporation of national sovereignty theory into American domestic law, neither process could be permissible. In reality, however, this example amply demonstrates that the role of comity withm the American legal system is routimely reduced to advance American interests abroad.

Another similar parallel arises from enforcement of American discovery orders in foreign nations. The American judicial process in these cases poses a direct affront to the laws of the countries concerned that is theoretically even more intrusive to sovereign interests than an extraterritorial arrest. ${ }^{121}$ Although arrest results from situations in which nations are unwilling or unable to produce fugitives, discovery frequently arises in direct conflict with foreign blocking statutes specifically intended to prohibit the exact actions the American order seeks to compel. ${ }^{122}$ American courts will nonetheless not give preclusive effect to the sovereign interests of the foreign state where they believe that American interests take precedence. ${ }^{123}$

\section{Policy Considerations Counseling Against Extraterritorial Arrest}

The legal framework provides broad deference to activities taken abroad by the executive branch irrespective of sovereignty concerns. Such deference within the domestic legal system does not, however, reheve American responsibilities under international law. ${ }^{124} \mathrm{~A}$ violation

119. See Rudolf B. Schlesinger et Al., Comparative Law 411 n.13 (5th ed. 1988) ("Many civil law countries require that service of process be effected by a local public official.").

120. Id. at 411 ("Many civil-law nations ... regard it as an infringement of their sovereignty if such official acts are performed within their territory by anybody other than their own judges and other officials."); see also RESTATEMENT (THIRD) OF THE FOREIGN RELATIONS LAW OF THE UNITED STATES $§ 432$ reporter's note 1 (1986) ("The states in whose territory such activity occurred have usually protested such action as violations of international law.").

121. See generally SchlESINGER ET AL., supra note 119, at 443-48. As the authors note, in some countries the taking of a deposition by a private person can lead to criminal liability. Switzerland has jailed foreign lawyers for doing so. Harry L. Jones, International Judicial Assistance, 62 YALE L.J. 515, 520, 528-29 (1953).

122. See, eg., Société Internationale Pour Participations Industrielles et Commerciales v. Rogers, 357 U.S. 197 (1958); see also RESTATEMENT (THIRD) OF THE FOREIGN RELATIONS LAW OF THE UNITED STATES § 442 reporter's note 1 (1986).

123. See, e.g., In re Grand Jury Proceedings, 691 F.2d 1384 (11th Cir. 1982), cert. denied, 462 U.S. 1119 (1983); In re Grand Jury Proceedings, 709 F. Supp. 192 (C.D. Cal. 1989).

124. This Note assumes, arguendo, that violations of state sovereignty for the purposes of arrest are not justifiable under international law. A tenable argument can be made that such operations can be legitimately conducted in defense of nationals, particularly when carried out as a military operation. Full development of the argument within the scope of this Note, however, would be prohibitive. For its broad contours, see Seizure Hearing, supra note 89, at 34 (statement of Abraham 
that is nieaningless under domestic law may mcur real consequences on the world stage. Respect for international law and state sovereignty is an important element of American foreign policy. ${ }^{125}$ Despite its presumptive legality, these policy considerations dictate that extraterritorial arrest cannot be considered as niore than an extraordinary remedy to be undertaken in pursuit of unusually important national interests.

Appearing on the same congressional panel with Barr, State Department Legal Adviser Abraham Sofaer took pams to delineate the pohcy limitations that international law places on extraterritorial arrest. ${ }^{126}$ Noting that "the United States has repeatedly associated itself with the view that unconsented arrests violate the principle of territorial imtegrity,"127 Sofaer acknowledged that "decisions about any extraterritorial arrest entail grave potential implications for U.S. personnel, for the United States, and for our relations with other states."128

The benefits of arrest would have to be weighed carefully in light of American interests implicated in a breach. Agents involved in the arrest are placed at personal risk. ${ }^{129}$ The United States might be open to civil suit in both the foreign country and international tribunals. ${ }^{130}$ Having estabhshed the precedent, the American government would not be well equipped to counter a similar "arrest" by a foreign nation in American

D. Sofaer) ("Despite its importance, however, the principle of territorial integrity is not entitled to absolute deference in international law.").

125. Considerations of sovereignty are, for example, of heightened concern to the administration where American territory is violated. Despite his approval of both opinions on extraterritorial arrest while heading the Office of Legal Counsel, Barr took a different view of sovereignty after becoming Attorney General. In discussing Justice Department plans to bolster immigration control on the Mexican border, Barr complained that "as we welcome people in the front door ... we see people crashing through the back door and the back window, violating our laws, flouting our sovereignty and ignoring our process." Haya El Nasser, Holes Punched in Border Plan: Won't Slow Illegal Flow, Critics Say, USA TODAY, Feb. 11, 1992, at A3.

126. The Legal Adviser has primary responsibility within the U.S. government for the advancement of international law. Current Developments, The Role of the Legal Adviser of the Department of State, 85 AM. J. INT'L L. 358, 358-59 (1991). Placed in an awkward position when the official administration position on extraterritorial arrest downplayed its importance, Judge Sofaer's remarks represent a delicate balancing act highlighting these concerns without countering the Justice Departinent's interpretation of domestic law.

127. Seizure Hearing, supra note 89, at 32 (statement of Abraham D. Sofaer). Judge Sofaer cited cases in which Canadian authorities arrested suspects within the United States. In 1876, Secretary of State Fish protested such an arrest on the grounds that "a violation of the sovereignty of the United States had been committed." Id. Conversely, when two bail bondsmen arrested a suspect in Canada, the State of Florida released the individual and deported the bondsmen to Canada, where they were convicted of kidnapping.

128. Id.

129. Id. at 39. Of note in the military context is Judge Sofaer's observation that "many States will not accord POW status to military personnel apprehended in support of an unconsented law enforcement action." Id.

130. Id. at 40 . 
territory. ${ }^{131}$ Most importantly, however, "[a]n unconsented, extraterritorial arrest would inevitably have an adverse impact on our bilateral relations with the country in which we act."132

Commentators on the new arrest pohcies expanded the State Department analysis, criticizing thein as improper means to return accused criminals to the Umited States. Focusing on American obligations under customary international law, they object to assertion of enforcenent jurisdiction abroad as offensive to foreign nations. ${ }^{133}$ These arguments quickly fizzle because of the subordinate status of customary law in the domestic regime. ${ }^{134}$ As a result, most recent scholarship has actually agreed that relevant considerations are pohcy-based rather than legal. ${ }^{135}$

Sensitive to such public perception that the broad interpretation of the law adopted by the Bush Administration might be used as an excuse for "cowboy diplomacy" abroad, Barr also recoguized that policy considerations could militate strongly against an otherwise permissible action. "The 1989 opimion," Barr noted in his prepared testimony, "takes no position supporting or opposing, as a policy matter, the use of the FBI or any other Executive Branch officials to make apprehensions in contravention of custoinary international law." 136 Under questioning by the Judiciary Committee, Barr said that he envisioned potential use of the

131. The reciprocity argument has been a favorite of critics of the extraterritorial arrest policy. See, e.g., Abraham Abramovsky, Extraterritorial Abductions: America's "Catch and Snatch" Policy Run Amok, 31 VA. J. INT'x. L. 151 (1991). The article dramatically opens with a scenario involving arrest of the CEO of ARAMCO by Iraqi agents for plundering the Rumalia oilfelds. See id.

Although the reciprocity argument has some analytical force, pragmatically it is of reduced importance. Foreign nations must weigh their own policy interests in making an extraterritorial arrest. Presumably, the prospect of facing the consequences of a violation of American sovereignty would be even less attractive than the list of negative factors noted by Sofaer. Further, American cooperation with international law enforcement efforts would leave little real justification for resorting to such measures. See Seizure Hearing, supra note 89, at 40 (statement of Abraham D. Sofaer).

132. Seizure Hearing, supra note 89 , at 40.

133. See, e.g., Abramovsky, supra note 131, at 201-02; Andreas F. Lowenfeld, U.S. Law Enforcement Abroad: The Constitution and International Law, 83 AM. J. INT'x. L. 880 (1989); Andreas F. Lowenfeld, Kidnapping by Government Order: A Follow-Up, 84 AM. J. INT'x. L. 712 (1990) [hereinafter Lowenfeld, Kidnapping].

134. Professor Lowenfeld candidly "acknowledge[s] that the reported decisions here and abroad did not, on the whole support my argnment." Lowenfeld, Kidnapping, supra note 133, at 712. Instead, he argues that "these decisions were out of step with contemporary mternational law and U.S. constitutional law." Id.

135. Professor Abramovsky does not contend that extraterritorial arrest must always be prohibited as a matter of law, but rather urges courts to invoke their supervisory powers to remedy violations of international law. See Abramovsky, supra note 131, at 190. The bulk of his arguments are made on policy grounds. See id. at 201-08.

136. Seizure Hearing, supra note 89, at 12. 
arrest authority only under "a limited range of circuinstances in the area of counterterrorisin and counternarcotics."137

Barr also noted that specific legal obligations to other nations could make extraterritorial enforcements legally impermissible in certain circumstances even under domestic law:138 "[T]lie 1989 opinion does not address the legal implications of deploying the FBI im violation of provisions of self-executing treaties or treaties that have been implemented by legislation."139 Sucl1 treaties can place significant tangible limitations on the freedom of the executive branch to pursue extraterritorial arrest. Altliougli the treaty issue will be subsequently discussed in more depth, ${ }^{140}$ it is important to note here that imternational agreements can pose significant legal roadblocks in the path of imternational arrests. ${ }^{141}$

For the most part, American imterests will comcide with pursuing arrest through regular extradition channels, specific "prosecute or extradite" agreements, ${ }^{142}$ or diplomatic cooperation. ${ }^{143}$ Where there are formal agreements, this may be the only legal option. In addition, the prospect of condemnation by the international commurity places a strong dismcentive on American policyınakers to pursue extraterritorial arrest where not clearly justifiable. ${ }^{144}$

Ultimately, however, some nations choose to support real threats to American security as an extension of national pohicy. When these countries assist others in lawbreaking, they cannot invoke the protections of legal norms that they themselves have cast aside. It is axiomatic that law enforcement authorities must sometinies themselves violate laws in the

137. Id. at 61 .

138. For cases considering the impact of specific treaties upon American legal obligation, see infra text accompanying notes 199-204.

139. Seizure Hearing, supra note 89 , at 12 .

140. See infra text accompanying notes 187-207.

141. Under questioning, for example, Barr told the subcommittee that "there's obviously no consideration whatever being given to this kind of operation in a situation like Colombia where the Government is actively cooperating with us and is engaged in extradition." Seizure Hearing, supra note 89 , at 68 .

142. Antiterrorisin treaties between the Umited States and foreign nations require the country in which the suspeet is present either to prosecute them through that nation's legal system, or extradite the parties to the nation which is targeted by their actions. See, e.g., International Convention Against the Taking of Hostages, G.A. Res. 146, U.N. GAOR, 34th Sess., Supp. No. 46, at 245, U.N. Doc. A/34/146 (1979) (signed December 17, 1979, entered into force June 4, 1983), reprinted in 18 I.L.M. 1456 (1979). Article 8 contains the alternate dnties to prosecute or extradite.

143. See Michael P. Scharf, The Jury Is Still out on the Need for an International Criminal Court, 1991 DukE J. COMP. \& INT'L L. 135, 149 ("[E]xperience has shown the existing system to be incrcasingly effective in bringing international criminals to justice.").

144. The paradigm case being the arrest of Adolf Eichmann in Argentina by Israeli agents. The move drew strong condemnation from the U.N. Security Council in response to the violation of Argentine sovereignty. The Council held that the act could "endanger international peace and security". U.N. SCOR, 15th Sess., 865th mtg. at 6, U.N. Doc. S/PV.865 (1960). 
line of duty. ${ }^{145}$ Barr explained the policy to the Judiciary Coinmittee: "The purpose of law is ultimately to protect innocent people from predators. And the people we're fighting are ruthless predators. They're not restrained by law. They inock the law, and they manipulate international rules of law to shield theinselves." 146

\section{Constitutional and TREaty Considerations}

Extraterritorial apprehension also inplicates legal questions under the Constitution, which grants guarantees to criminal suspects under the Bill of Rights and mandates observance of treaties as the supreine law of the land. Although almost all authoritative judicial opinion has found that extraterritorial arrest cannot be said to be illegal per se under the Constitution, ${ }^{147}$ improper conduct during an arrest can invalidate the arrest. Further, the executive branch must take special care to observe proper procedure regarding international agreements.

\section{A. Constitutional Issues}

Constitutional issues that involve extraterritorial arrest reduce to two fundamental questions. First, does the Constitution apply abroad? Second, what guarantees does the Constitution provide to a suspect who is arrested overseas? ${ }^{148}$ The Supreine Court has already dealt directly and indirectly with these core questions, and its answers so far have not encouraged advocates of strong restraint on law enforcement abroad.

1. Extraterritorial Scope of Constitutional Provisions. In United States v. Verdugo-Urquidez, ${ }^{149}$ Chief Justice Rehnquist wrote for the Court that the Fourth Amendment's Warrant Clause did not apply to the search of an alien's residence in Mexico. The majority determined

145. Authority for executive branch agents to do so is recognized in In re Neagle, 135 U.S. 1 (1890). In that case, U.S. Marshal David Neagle shot and killed an assailant while protecting Supreme Court Justice Field. Justice Miller wrote that "[T]he marshal of the United States . . . being present at the critical moment, when prompt action was necessary, found it to be his duty, a duty which he had no liberty to refuse to perform, to take the steps which resulted in Terry's death." Id. at 69 .

146. Seizure Hearing, supra note 89, at 64 .

147. See Paul B. Stephan III, Constitutional Limits on International Rendition of Criminal Suspects, 20 VA. J. INT'L. L. 777, 800 (1980) ("[C]ourts have sought to impose strong penalties for what is clearly unpalatable but not necessarily unconstitutional action. The resulting analytical confusion has produced precedents that . . . run counter to current doctrine.").

148. Professor Stephan first offered this framework and provided a third question: What remedies are available for violations? See id. at 777-78. His article examines the conceptual issues and history that underlie these questions more thoroughly than the brief analysis here.

149. 494 U.S. 259 (1990). 
the case along two lines of argument; its significance in the greater scheine will depend on which endures in later analysis.

The first, seemingly technical, argument, is based on the text of the Fourth Amendment. The Amendinent guarantees that " $[t]$ he right of the people to be secure in their persons, houses, papers, and effects, against unreasonable searches and seizures, shall not be violated."150 Chief Justice Relinquist interpreted the phrase "the people" to inean only American citizens, who bind the government through the contract of the Constitution. "While this textual exegesis is by no ineans conclusive, it suggests that 'the people' protected by the Fourth Amendment ... refers to a class of persons who are part of a national cominunity or who have otherwise developed sufficient connection with this country to be considered part of that commumity."151 Under such a narrow justification, this argument inay only have force where the exact words of the Constitution allow its apphication. ${ }^{152}$

The language of the inajority opinion in Verdugo-Urquidez suggests, however, that the case inay stand for the broader proposition that forms the Court's second arguinent. One of the ongoing debates in constitutional jurisprudence is whether the United States is bound in all cases by the docuinent, or if instead it is a coinpact between the citizenry and its government. ${ }^{153}$ In rejecting Verdugo-Urquidez's citation of Reid v. Covert, ${ }^{154}$ Chief Justice Relinquist effectively rejected the first theory. "Reid stands for no such sweeping proposition," he wrote. ${ }^{155}$ According to the

150. U.S. CONST. amend. IV.

151. Verdugo-Urquidez, 494 U.S. at 265-66 (citing United States ex rel. Turner v. Williams, 194 U.S. 279, 292 (1904) (holding that an excludable alien is not entitled to First Amendment rights because "[h]e does not become one of the people to whom these things are secured by our Constitution")).

152. See Ruth Wedgwood, Decision: United States v. Verdugo-Urquidez, 84 AM. J. 1NT'L L. 747, 750 (1990). Defendants hoping to test other constitutional provisions governing actions taken abroad would be ill-advised to rely on the Fifth Amendment, as Chief Justice Rehnquist also explicitly ruled it out on the same basis. See Verdugo-Urquidez, 494 U.S. at 269. It is important to note, however, that Fifth Amendment trial rights still appear to apply, because the trials occur within "the sovereign territory of the United States." Id.

153. The compact theory is recognized by Chisholm v. Georgia, 2 U.S. (2 Dall.) 419, 471 (1793) ("[T]he Constitution of the United States is ... a compact made by the people of the United States to govern themselves."). The organic theory, which argues that the Constitution binds the government in all actions, is advocated in Note, The Extraterritorial Applicability of the Fourth Amendment, 102 HARV. L. REv. 1672 (1989); see also Roszell D. Hunter IV, Note, The Extraterritorial Application of the Constitution-Unalienable Rights?, 72 VA. L. REV. 649, 651-53 (1986).

154. 354 U.S. 1 (1957). Specifically, Verdugo-Urquidez attempted to use language from the opinion to argue that the government was always bound by constitutional provisions. "The United States is entirely a creature of the Constitution. Its power and authority have no other source. It can only act in accordance with all the limitations of the Constitution." Id. at 5-6 (footnote omitted). Reid arose in the context, however, of U.S. military personnel stationed abroad.

155. Verdugo-Urquidez, 494 U.S. at 270. 
majority, Verdugo-Urquidez's ties to the United States were simply insufficient to invoke constitutional rights abroad. ${ }^{156}$

Adoption of the compact theory finds some additional force in United States v. Curtiss-Wright Export Corp. ${ }^{157}$ not directly cited in that section of the opinion. Curtiss-Wright is most frequently cited to illustrate presidential authority over foreign affairs. More insportantly in this context, however, its finding is based on the conclusion that "[n]either the Constitution nor the laws passed in pursuance of it have any force in foreign territory unless in respect of our own citizens."158 The absence of reliance on this dicta im the Verdugo-Urquidez opimion may indicate that the Court wished only to avoid adopting the orgamic theory without fully endorsing the compact theory.

Because the Court did not make its point explicitly, it is unclear if any rule applies in all circumstances. ${ }^{159}$ The reluctance of the Rehnquist Court to apply constitutional provisions broadly to an extraterritorial law enforcement action, however, suggests that challenges to such arrests may not even succeed in reaching a learing on the merits.

Over and above the general applicability of the Constitution to aliens abroad, the Court also considered its force in the context of national security. In a passage particularly important to the subject matter of this Note, Chief Justice Rehnquist suggested that American activities abroad would receive particular leeway when effectuating national policy

156. See id. The opimion did note, however, that in some cases non-citizens could invoke constitutional rights. Id. at 269 (citing Johnson v. Eisentrager, 339 U.S. 763, 770 (1950) ("The alien . . . has been accorded a generous and ascending scale of rights as he incrcases his identity with our society.")).

Conversely, citing concurring opmions by Justices Frankfurter and Harlan in Reid, Chief Justice Rehnquist implied that even American citizens might be unable to take advantage of some parts of the Constitution abroad. "[They] declimed even to hold that United States citizens were entitled to the full range of constitutional protections in all overseas criminal prosecutions." Id. at 270.

This analysis squares with the Court's decision in In re Ross, 140 U.S. 453 (1891), which rejected the idea that all "protection[s] and guarantee[s] . . . secured by the Constitution to citizens of the United States at home, should be enjoyed by them abroad." Id. at 463 . In some circumstances, the court is willing to hold that the Constitution "can have no operation in another country." Id. at 464.

157. 299 U.S. 304 (1936).

158. Id. at 318. Presumably "in respect of our own citizens" allows exercise of prescriptive jurisdiction abroad against foreign nationals. Importantly, however, the Court held that treaties and principles of international law stood in the Constitution's stead in limiting options of the executive branch. See id. This important limitation is discussed infra at notes 187-207 and accompanying text.

159. Editorial commentators did not hesitate to read the opinion broadly. See, e.g., William Pfaff, The High Court's Pernicious Ruling That "We're No. 1", CHI. TRIB., Mar. 6, 1990, at 17 ("The Supreme Court holds that American national interest is superior to a foreign person's claim to security in his or her person and house."). 
interests as opposed to routine law enforcennent. His opinion iniplied that actions by the armed forces would receive even inore deference:

[T] he result of accepting [the organic] claim would have significant and deleterious consequences for the United States in conducting activities beyond its boundaries. The rule ... would apply not ouly to law enforcement operations abroad, but also to other foreign policy operations whicli miglit result in "searclies or seizures." The United States frequently employs armed forces outside this country-over 200 times in our history - for the protection of American citizens or national security. Application of the Fourtli Amendment to those circunstances could significantly disrupt the ability of the political branclies to respond to foreign situations involving our national interest. ${ }^{160}$

A President who conteinplates deployinent of military force for law enforceinent goals related to national security could scarcely have stronger support. Under this analysis, the steady progression of deference to the executive seeins to have reached its zenith. The Ship Richmond allows the executive to override the relatively weak legal force provided by customary international law within the United States. Chief Justice Rehnquist's analysis in Verdugo-Urquidez hints that the Suprenie Court could be willing to allow Presidential power under Article II to override even the Bill of Rights in limited circunstances concerning aliens. The basic principle has niade extraordinary appearances in past Supreme Court decisions implicating national security, but never so bluntly in a conteniporary case. ${ }^{161}$

The implications of the opinion may seein harsh, leaving, in theory, unfettered discretion in the hands of the executive branch. To adopt the opposite position and extend constitutional protections to aliens in all circunistances, however, would have an even more profound impact. Justice Jackson explained the logic in Johnson v. Eisentrager: ${ }^{162}$

[A broad construction of the Constitution] would mean that during military oceupation irreconcilable enemy elenents, guerilla figliters, and "werewolves" could require the American Judiciary to assure them freedom of speecl, press, and assembly, as in the First Amendneent, right to bear arms as in the Second, security against "unreasonable" searclies and seizures as in tlie Fourtli, as well as rights to jury trials as in tlie Fiftli and Sixtli Amendnents. ${ }^{163}$

160. Verdugo-Urquidez, 494 U.S. at 273-74 (citation omitted).

161. Korematsu v. United States, 323 U.S. 214 (1944), stands strongly for the principle. As widely discredited as Korematsu has been, it seems noteworthy that Verdugo-Urquidez appears to have reaffirmed its essence. Importantly, however, the events in Korematsu took place in the United States and concerned American citizens, contrary to the core theories in Verdugo-Urquidez.

162. 339 U.S. 763 (1950).

163. Id. at 784. 
In modern times where large-scale military occupation is rapidly becoming anachronistic, this discussion from 1950 does not seem particularly persuasive. Justice Jackson's basic logic, however, has enduring value in an nicreasingly complex world. Professor Stephan extended Jackson's analogy:

Those citizens of North Vietnam who suffered risk of a "taking" of "life" without "due process" during the bombing of that country could have sought an injunction against the raids based on the fifth amendment, and survivors of those killed now could seek dainages against our governinent. Those Iranians who were temporarily detained in the desert during the unsuccessful atteinpt to rescue the U.S. hostages could sue for violations of their fourth amendinent rights. Foreign leaders everywhere could seek to enjoin the surveillance of their actions by U.S. intelligence services. ${ }^{164}$

Chief Justice Rehnquist's holding in Verdugo-Urquidez thus appears not to be aimed at nationalistic expansion of American jurisdiction, but rather at real practical and legal problems that would arise under different law. General challenges to extraterritorial arrest on constitutional grounds in American courts could result in a flood of hitigation challengmg foreign policy decisions. This type of case is the essence of the nonjusticiable pohtical question. ${ }^{165}$

2. Specific Constitutional Provisions. Whether or not aliens inay mvoke the Constitution in challenging alleged breaches outside American territory ultimately is a moot point when considering military arrest. Even assuming that the text applies, no provision of the Constitution seenis to prevent overseas arrest per se. As Justice Black put it, "[t]here is nothing in the Constitution that requires a court to permit a guilty person rightfully convicted to escape justice because he was brouglit to trial against his will."166

Legal challenges to enforcement operations abroad most logically center on the Fourth and Fifth Amendnients. ${ }^{167}$ The majority of Fourth Amendment cases arise from a lack of probable cause or issuance of a

164. Stephan, supra note 147 , at 786 .

165. See Baker v. Carr, 369 U.S. 186, 217 (1962). Such cases contain both "a textually demonstrable commitment of the issue to a coordinate political department" and "a lack of judicially discoverable and manageable standards for resolving it." Id. In the military context, see also Gilligan v. Morgan, 413 U.S. 1, 10-11 (1973) (holding suit challenging training standards of Ohio National Guard to be a political question, because it would require courts to supervise Guard activities).

166. Frisbie v. Collins, 342 U.S. 519, 522 (1952).

167. See Extraterritorial Apprehension by the Federal Bureau of Investigation, 4B Op. Off. Legal Counsel 543, 553 (1980) ("There are two constitutional arguments available to [the fugitive]. The first is that he is subject to an unreasonable search and seizure in violation of the Fourth Amendment. The second is the Fifth Amendment due process argument ...."). 
proper warrant. ${ }^{168}$ Fifth Amendment claims cover a range of conduct that might deprive suspects of due process rights. Where the special abilities of nilitary units prove necessary to arrest a given suspect, they stand in the stead of more conventional law enforcement. 169 Such use is entirely consistent with the Constitution, which has never been read to prohibit extraterritorial arrest per se. ${ }^{170}$ However, military units that conduct arrests should take care to coniply with the constitutional standards that would otherwise apply.

Fifth Amendnent doctrines nicely illustrate the point. In $\mathrm{Ker} v$. Illinois, ${ }^{171}$ the Suprene Court refused to find a due process violation where the suspect was arrested in Peru and brought to the United States. "[U]nless there was sone positive provision of the Constitution or of the laws of this country violated in bringing him into court, it is not easy to see how he can say that he is there 'without due process of law,' within the neaning of the constitutional provision."172 The Court continued:

The 'due process of law' here guaranteed is complied with when the party is regularly indicted by the proper grand jury im the State court, [and] has a trial .... [B] ut, for mere irregularities in the manner in which he may be brought into the custody of the law, we do not think he is entitled to say that he should not be tried at all for the crime with which he is charged in a regular indictment. ${ }^{173}$

Ker has reniained largely undisturbed to the present day. ${ }^{174}$ Courts inay still invahidate arrests on due process grounds, however, where the conduct of the agents inaking the arrest constitutes "cruel, inhuman, and outrageous treatnient." 175 The doctrine sten1s from United States v. Toscanino, ${ }^{176}$ a leading case addressing egregious conduct in extraterritorial

168. See, e.g., Gerstein v. Pugh, 420 U.S. 103, 126 (1975).

169. When American troops went to Panama in 1989, President Bush issued a memorandum to Secretary of Defense Cheney directing and authorizing military units to apprehend Noriega and others under indictment. He apparently did so solely under his executive authority, and ordered that any persons apprehended were to be turned over to civil law enforcement as soon as possible. See Memorandum Directing the Apprehension of General Manuel Noriega and Others in Panama Indicted in the United States for Drug-Related Offenses, 25 WeEkly CoMP. Pres. Doc. 1976 (Dec. 20, 1989).

170. See United States v. Yunis (Yunis III), 924 F.2d 1086, 1094 (D.C. Cir. 1991) ("Nor would a violation of the [Posse Comitatus] regulations at issue amount to a constitutional violation, making application of an exclusionary mle or similar prophylactic measures inappropriate.").

171. 119 U.S. 436 (1886).

172. Id. at 440 .

173. Id.

174. See Frisbie v. Collins, 342 U.S. 519, 522 (1952) ("This Court has never departed from the rule announced [in $\mathrm{Ker}$ ] that the power of a court to try a person for crime is not impaired by the fact that he had been brought within the court's jurisdiction by reason of a 'forcible abduction.' ").

175. United States ex rel. Lujan v. Gengler, 510 F.2d 62, 65 (2d Cir.), cert. denied, 421 U.S. 1001 (1975).

176. 500 F.2d 267 (2d Cir. 1974). 
arrest. ${ }^{177}$ Toscanino is based in soine respects on a strained legal foundation, and its holding has not been closely followed in subsequent cases or by other circuits. ${ }^{178}$ The case still has value, however, as a deinonstration of impermissible conduct in a particular arrest that inight rise to the level of a due process violation, despite a general presumption under $\mathrm{Ker}$ that irregular arrest itself cannot provide a basis for disinissal. ${ }^{179}$

The Toscanino principle is particularly attractive to courts that wish to inaintain supervisory control over arrests of suspects brought before thein. Simply because the executive branch has acted to apprehend a suspect does not inean that the judiciary inust becoine "accoinplices in willful disobedience of law."180 As Judge Oakes stated:

[W] can reach a time when in the interest of establishing and naintaining civilized standards of procedure and evidence, we may wish to bar jurisdiction in an abduction case as a matter not of constitutional law but in the exercise of our supervisory power. ... To my mind the Government in the laudable interest of stopping the international drug traffic is by these repeated abductions inviting exercise of that supervisory power in the interest of the greater good of preserving respect for the law. ${ }^{181}$

Such a formulation strikes a balance between the state interest in bringing criminal suspects to justice and the rights of the individual to be treated fairly. Finding the boundaries of "egregious" conduct, however, inay prove soinewhat subjective. ${ }^{182}$ But in the end, the due process analysis reaffirms two key points: One, nothing in the Constitution prohibits

177. Toscanino's case seems to stand as a paradigm of subjectively unacceptable government conduct. Agents lured Toscanino, accused of conspiracy to import narcotics into the United States, and his pregnant wife from their home to a Montevideo bowling alley. Once there, seven agents knocked him unconscious and threw him into a car. In the car, he was blindfolded and bound. The car took a circuitous route to the Brazilian border. In route, the agents discussed changing license plates to avoid the Urugnayan police, and, while the car was stopped, the agents held a gun to Toscanino's head to make him hold still to avoid detection. Id. at 269.

178. The Toscanino court atteinpted to distinguish $\mathrm{Ker}$ against the backdrop of a constitutional due process "revolution," and argued that the Fifth Amendinent was no longer "limited to the guarantee of 'fair' procedure at trial." Id. at 272. Its support came from seemingly inapposite cases such as Mapp v. Ohio, 367 U.S. 643 (1961) (extending Fourth Amendment exclusionary rule to states through Fourteenth Amendment).

Other circuits have rejeeted this reformation and continued to follow Ker. See, e.g., United States v. Rosenthal, 793 F.2d 1214, 1232 (11th Cir. 1986); United States v. Marzano, 537 F.2d 257, 271-72 (7th Cir. 1976), cert. denied, 429 U.S. 1038 (1977).

179. Lujan recognized this distinction. See 510 F.2d at 66.

180. McNabb v. United States, 318 U.S. 332, 345 (1943).

181. United States v. Lira, 515 F.2d 68, 73 (2d Cir.) (Oakes, J., concurring), cert. denied, 423 U.S. 847 (1975).

182. One example is particularly appropriate to the analysis within the context of both due process and military law enforcement. While making an carly ruling in the trial of General Noriega, Judge Hoeveler was forced to confront a unique fact pattern in drawing lines of acceptable conduct within the Toscanino framework: 
law enforcement by military units; and two, those units may not, however, engage in unconstitutional conduct in the course of making arrests.

One brief example under Fourth Amendment analysis denionstrates that the executive will follow important requirements of the criminal justice system, despite the fact that the Constitution might not strictly require him to do so. Following the arrival of U.S. troops in Panama, General Manuel Noriega successfully evaded capture for days, finally taking asylum in the Papal Nunciature in Panama City. American troops surrounded the building, joined by thousands of agitated Panamanians. After eleven days of standoff, Noriega finally surrendered to the troops. The tense encounter grew to a climax as armed Army officers carefully escorted him by military helicopter to Howard Air Force Base and the object of the confrontation: Drug Enforcement Agency operatives waiting to fulfill the letter of the Fourth Amendment. ${ }^{183}$ The agents arrested Noriega pursuant to the indictment pending against him in Florida and escorted him there on an uneventful trip by cargo plane. ${ }^{184}$

The facts need not be put so dramatically except to prove a point. Consideration of military arrest inevitably focuses on the power that the troops might bring to bear in the course of the operation. It does not follow, however, that any arrest in such circunistances inust be violent or outside the basic boundaries of procedure. There is no evidence that the Army mistreated Noriega in any way. ${ }^{185}$ A warrant may not have been constitutionally necessary under the circumstances. ${ }^{186}$ Nonetheless, the juggernaut of the U.S. Southern Cominand served only one law enforcement function - the quiet delivery of Noriega to two DEA agents carrying an arrest warrant.

On the present record, the only incident which comes close to any kind of personal mistreatment is the above mentioned event in which American troops blasted the Papal Nnnciatnre in Panama City with loud rock-and-roll music in an apparent effort to drive Noriega ont. While there are those who might consider contimued exposure to such music an Eighth Amendment violation, it is the opinion of the Court that such action does not rise to the level of egregious misconduct sufficient to constitute a due process violation.

United States v. Noriega, 746 F. Supp. 1506, 1531 n.27 (S.D. Fla. 1990).

183. Id. at 1511 .

184. Id.

185. See id.

186. Exemption from the warrant requirement is recognized where "the exigencies of the situation made that course imperative." McDonald v. United States, 335 U.S. 451, 456 (1948). In addition, as Chief Justice Rehnquist noted in Verdugo-Urquidez, a warrant in Panama would have been "a dead letter outside the United States." United States v. Verdugo-Urquidez, 494 U.S. 259, 274 (1990). The approach is imconsistent because a warrant presumably should accompany assertion of enforcement jurisdiction. Nonetheless, it deinonstrates that the executive took particular pains to meet constitutional requirements in the Noriega case. 


\section{B. Treaties and International Agreements}

Treaties and other international agreements can pose significant potential obstacles to the exercise of enforcement jurisdiction abroad by American military forces. ${ }^{187}$ Where the executive branch has expressed consent to be bound by extradition agreements with foreign nations, ${ }^{188}$ such commitments stand under the Constitution as the supreme law of the land. ${ }^{189}$ Treaties that provide the exclusive means for recovering fugitives in other nations technically may be read to preclude other means of arrest as long as they remain in force. 190

Practically speaking, however, international agreements will usually prove imsufficient to defeat exercise of enforcement jurisdiction abroad for three reasons. First, failure of the asylum state to produce fugitives might constitute a breach of the agreement sufficient to allow the United States permissibly to take action outside the text of the treaty. Second, the constitutional authority of the executive branch over treaties and national security allows it to suspend or terminate extradition agreements. This power additionally allows the President to protect high level national interests irrespective of treaty provisions. Finally, although there is some conflict im the area, it appears that federal courts may refuse to invalidate arrests on the ground that an extradition treaty is the exclusive lawful means to capture fugitives in other countries.

1. Treaty Breach Relieves Obligations. When another nation refuses to produce a fugitive located within its territory despite an extradition agreement that obligates it to do so, it breaches the treaty. ${ }^{191}$

187. The Supreme Court has granted certiorari to determine the legal status of extraterritorial arrest conducted contrary to an international agreement. See United States v. Alvarez-Machain, 946 F.2d 1466 (9th Cir. 1991), cert. granted, 112 S. Ct. 857 (1992). The arguments in this case are discussed at some length in Mitchell J. Matorin, Note, Unchaining the Law: The Legality of Extraterritorial Abduction in Lieu of Extradition, 41 DuKE L.J. 907 (1992). Although it is possible that the Court will visit all of the areas of the law discussed in this section, it is more likely that a decision in Alvarez-Machain will be made on narrower grounds. Accordingly, this Note will make its arguments refiecting the law as of early 1992, subject to any changes that may be forthcoming in the decision.

188. A list of the nations with which the United States has entered into extradition treaties is available in the notes after 18 U.S.C. $\S 3181$ (1988). In the absence of a treaty, extraterritorial arrest would be governed solely by the considerations of comity discussed supra at text accompanying notes 107-21.

189. See U.S. CoNSr. art. VI, cl. 2

This Constitution, and ... all Treaties made, or which shall be made, under the Authority of the United States, shall be the supreme Law of the Land; and the judges in every State shall be bound thereby, and any Thing in the Constitution or Laws of any State to the Contrary notwithstanding.

190. See, e.g., Extradition Treaty, Jan. 21, 1977, U.S.-U.K., 28 U.S.T. 227.

191. RESTATEMENT (ThiRd) OF THE Foreign Relations LAW OF THE UNited STATES $\S 475$ (1986). This assumes that other principles governing extradition and specific treaty provisions 
Although each government retains some discretion to refuse extradition requests, failure to comply usually opens it to reprisals by the other party to the agreement. ${ }^{192}$ Such reprisals can include suspension or termination of the reciprocal obhigations of the country demanding the criminal suspect. ${ }^{193}$ Breach by the asylum state may void any restraints imposed by treaty and leave the American government free to legally pursue selfhelp inconsistent with the agreement under both imternational and domestic law. 194

To fully justify extraterritorial apprehension as a remedy, the American government would have to comply with procedural requirements to place the action in the proper legal context. Presumably, it could not mvoke a "breach" by the asylum state if it had never taken the proper steps to request extradition. ${ }^{195}$ Further, the Vienna Convention by its own terms provides the sole guidelines governing suspension and termination of international agreements. ${ }^{196}$ To end its obhigations lawfully, treaty law requires notification both that the aggrieved nation considers the treaty to be in breach and of what actions it may take to remedy the

would require delivery of the fugitive. If the suspect had been accused of an offense that is not a crime in the asylum state, for example, the principle of double criminality could preclude extradition. A list of general considerations that can allow a nation to refuse extradition can be found in $i d$. $\$ 476$. Because many treaties allow nations to make discretionary refusals to produce fugitives, breach must teclnically be inferred in some instances from a refusal to meet treaty obligations in good faith.

192. See id. $\S 475 \mathrm{cmt}$. g.

193. See Vienna Convention on the Law of Treaties, May 23, 1969, 8 I.L.M. 679 (Although the United States is not a party to the Vienna Convention, the agreement codifies inost of the customary international law of treaties.). Article 60 , section 1 provides that "[al material breach of a bilateral treaty by one of the parties entitles the other to invoke the breacl as a ground for terminating the treaty or suspendimg its operation in whole or in part." Id. at 701. Seetion 3 defines a material breach in part as "the violation of a provision essential to the accomplishment of the object or purpose of the treaty." Id.

194. Cliarlton v. Kelly, 229 U.S. 447,473 (1913).

195. Scrupulous adlerence to the requirements of the law in pursuit of Libyan intelligence operatives suspected of bombing Pan Am flight 103 is one example of how these requirements are fulflled in practice. See Elaine Sciolino, U.S. and Its Allies to Move on Libya over Air Bombings, N.Y. Times, Dec. 19, 1991, at Al ("The three Governments [United States, United Kingdom, Francel appear to be moving toward a step by step approach that mirrors the strategy used against Iraq after its invasion of Kuwait in August 1990.").

196. Vienna Convention on the Law of Treaties, supra note 193, art. 42, para. 2, at 696 ("The termination of a treaty, its denunciation or the withdrawal of a party, may take place only as a result of the application of the provisions of the treaty or of the present Convention. The same rule applies to suspension of the operation of a treaty."). 
violation. ${ }^{197}$ Although these requirements pose no more than a formalistic hurdle to arrest abroad, conscientious adherence could defeat treatybased objections to arrest at a fundamental level. ${ }^{198}$

2. Constitutional Authority of the Executive Branch. Along with the authority to oversee national defense, the executive branch also supervises the negotiation and termination of treaties. ${ }^{199}$ Insofar as an extraterritorial arrest represents a political decision by the President in furtherance of these duties, nullification by the judiciary based on treaty provisions interferes unconstitutionally with that textually committed discretion. ${ }^{200}$ If a President chooses to terminate a treaty by executive action, it is inconsistent for a court to dictate that the treaty is, in its view, in force.

Although courts have an acknowledged role in adjudicating individual rights under established treaties, ${ }^{201}$ past cases have recognized that broader issues where treaty status is uncertam are generally outside judicial cognizance:

[I]t is not "a judicial question, whether a treaty with a foreign sovereign has been violated by [the President] ... whether the views and acts of a foreign sovereign, manifested through his representative have given just occasion to the political departments of our government to withhold the execution of a promise contamed in a treaty, or to act in direct contravention of sucl promise.... These powers liave not been confided by the people to the judiciary, which has no suitable means to exercise them; but to the executive and the legislative departments ...."202

197. Id. art. 65, paras. 1-2, at 703. The Vienna Convention in theory inposes a three-month waiting period before any reprisal action may be taken. The agreement waives the waiting period, however, in cases of special urgency. An apprehension could be easily justified before the tolling of the three months, in that fugitives undoubtedly would be encouraged to flee by scrupulous observation of the deadline.

198. The most prominent and thoroughly researched contemporary case on the interrelationship between treaty law and extraterritorial arrest provides practical proof of the point. See United States v. Verdugo-Urquidez, 939 F.2d 1341 (9th Cir. 1991). That case makes no mention of the reciprocal obligations of asylum states. The reason for this is because the United States never requested extradition in the case. The court refused to uphold the arrest.

199. See U.S. CoNST. art. II, $\S 2$, cl. 2 (empowering the President to make treaties with the advice and consent of the Senate). The power to terminate treaties has been inferred as accompanying this power, especially where ternination by breach is alleged. See, e.g., Charlton y. Kelly, 229 U.S. 447, 476 (1913) (holding that executive department has discretion over tennination of treaties).

200. Arguably, the matter constitutes a noncognizable political question. See Baker v. Carr, 369 U.S. 186, 217 (1962).

201. See Restatement (Third) of the Foreign Relations LaW of the United States $\S 326(2)$ (1986).

202. Taylor v. Morton, 23 F. Cas. 784 (C.C.D. Mass. 1855) (No. 13,799); accord Foster v. Neilson, 27 U.S. (2 Pet.) 253, 309 (1829). 
As seen in so inany other areas of the law, treaty issues involving military judgment also require special deference to the President.203 Broad reading of treaty provisions in national security situations could significantly inpair the ability of the executive to carry out its constitutional functions. Because treaty provisions inconsistent with the Constitution are void, ${ }^{204}$ no treaty could practically be read to prohibit a inilitary action. Such a result could not be properly reconciled with the constitutional authority of the judiciary.

3. Exclusivity of Treaty Provisions. The majority of recent cases concerning extraterritorial apprehension have dealt with issues less sweeping than the overall validity of treaties or judicial interpretation. Instead, they have focused on the practical issue of whether an extradition treaty provides the sole means for recovernig fugitives in other nations. ${ }^{205}$ Because the question is extensively discussed elsewhere in this issue of the Duke Law Journal, ${ }^{206}$ this Note will only mention it as a relevant consideration. Although domestic courts will seemingly not define treaties as the sole remedy, ${ }^{207}$ the ternis of most treaties represent a commitment by the Umited States to follow thein in requesting surrender of fugitives abroad. To remain fully consistent with the law, pohicymakers should take the appropriate steps to present arrest abroad as a remedy for treaty breach rather than take unilateral action outside the agreeinent.

\section{CONCLUSION}

Any situation that involves the issue of extraterritorial arrest represents a fundamental breakdown in international relations, especially where the United States inust consider the use of armed forces as a reinedy. The President inust retain discretion to defend American national interests abroad, and the law grants wide latitude to the executive in taking appropriate steps to do so. When steps taken in response include law enforceinent activity, legal issues becoine entangled with national security policy, leaving courts to determine the appropriate level of intervention in reviewing such actions.

203. See, e.g., Clark v. Allen, 331 U.S. 503 (1947).

204. See Reid v. Covert, 354 U.S. 1 (1957).

205. See, e.g., Verdugo-Urquidez, 939 F.2d at 1342.

206. See Matorin, supra note 187.

207. Id. at 912-23. International law assumes that treaties are the only means to compel recovery of fngitives abroad. This assnmption is based, however, solely on considerations of sovereignty discussed supra notes 91-123 and aecompanying text. 
Courts have wisely recognized that considerations of international comity and defense policy fall outside the scope of judicial review, which must be himited to its traditional role of ensuring that defendants receive full and fair adjudication of their individual cases. Ultimately, legal considerations in overseas seizures are reduced to this simple issue. For although any chain of events ending in such an arrest inust inevitably involve broad ramifications on an international scale, in the end, the law is asked to do no more than address the acts of those who set the chain in inotion. 